\title{
The Mediator Role of Spousal Self-Disclosure in the Relationship between Marital Satisfaction and Spousal Support*
}

\author{
Pınar Çă $\breve{g}^{1}$ \\ Middle East Technical University
}

\author{
İbrahim Y1ldırım ${ }^{2}$ \\ Hacettepe University
}

\begin{abstract}
This study addresses the mediator role of spousal self-disclosure in the relationship between the spousal support and satisfaction with the marriage. For this purpose, data was collected from 549 married volunteers who lived in Ankara, had a wage-earning job, and who were at least high-school graduates. The married participants of the study were applied the data collection instruments of "Marital Life Scale", "Spousal Support Scale" and "Self-Disclosure to Spouse Scale". A relational screening model was used to study the relationship among the variables of spousal support, satisfaction with the marriage, and spousal self-disclosure. The mediator role of spousal self-disclosure in the relationship between spousal support and satisfaction with the marriage was tested by a structural equality model. The software LISREL 8.8 was used to test the model of the study. The relations among the variables were analyzed by path coefficients. Based on an examination of the path coefficients, the hypothesis that the mediator role of spousal self-disclosure in the relationship between the latent variable of spousal support and marital satisfaction is statistically significant was accepted. In sum, the mediation effect of the variables of spousal self-disclosure and the spousal support explain marital satisfaction. The findings of the study revealed that the variable of spousal self-disclosure has a full mediator role in the relationship between marital satisfaction and spousal support. As a result of these findings, it is fair to say that married couples who disclose themselves more deeply and sincerely to each other have a stronger and more effective perception of intimacy and support, thus married couples are able to display more flexible and appropriate behaviors to their spouse, improving the quality of their support with the advantages of self-disclosure. One can say that a healthy self-disclosure between the couples makes the social support that the spouses perceive from each other clear, fluent and fit for the needs, and increase their marital satisfaction. In this study, marital satisfaction was analyzed under a structural model with the variables of spousal support and spousal self-disclosure. Marital satisfaction may be examined with different variables that may be supported with theoretical grounds to plan new research.
\end{abstract}

\section{Keywords}

Marital satisfaction $\bullet$ Spousal support $\bullet$ Self-disclosure to spouse $\bullet$ Structural equality model $\bullet$ Mediator role

\footnotetext{
* This paper was prepared from the doctoral dissertation which was named "Marital Satisfaction: A model testing".

An earlier version was presented at "Frontline: Combat and Cohesion in Iraq and Afghanistan," a conference held at All Souls College, Oxford University, March 2013.

1 Correspondence to: Pınar Çăg (Doctor Instructor), Center for Advancing Learning and Teaching, Middle East Technical University, Ankara 06800 Turkey. Email: cpinar@metu.edu.tr

2 Department of Guidance and Psychological Counseling, Hacettepe University, Ankara Turkey. Email: iyil@hacettepe.edu.tr Citation: Çağ, P., \& Yıldırım, İ. (2018). The mediator role of spousal self-disclosure in the relationship between marital satisfaction and spousal support. Educational Sciences: Theory \& Practice, 18, 701-736. http://dx.doi.org/10.12738/estp.2018.3.0086
} 
One of the most important close relationships, marriage is a relationship which is made in a ceremonial structure, puts couples into a socially-accepted type of relationship and has different social sanctions (Burgess, Locke, \& Thomes, 1963). Marriage is a significant life event that occupies a remarkable place in the lives of many women and men (Berscheid \& Regan, 2005), and an essential stage of turning into an adult and starting a family (Kublay \& Oktan, 2015). It is as old as the mankind (Juvva \& Bhatti, 2006), and a complex relationship structure that requires a consistent sexual engagement under certain rules and conventions (Blood, 1969; Lantz \& Synder, 1969).Other needs in the formation of close relations like marriage include making the relationship deeper, acting more freely, comfortably and like oneself around the partner, making physical intimacy more integral, enhancing psychological intimacy in this context, unifying the similarities and differences, and stretching the relationship rules and maintaining the relationship in a deeper flow (Duck, 1988). One may attach a greater importance to marriage for a more direct and strong relationship with well-being compared to the social bonds such as family and friendship among the types of close relationship (Blood, 1969; Pateraki \& Roussi, 2013). The relationships established in a lifetime are a guiding force in the life of an individual. The level and course of such close relationships may decrease or increase the individuals' levels of physiological and psychological health, self-esteem and life satisfaction. Therefore, for many individuals, improving self-confidence, disclosing oneself comfortably to their spouse, and expecting to be satisfied with the relationship are crucial aspects of a close relationship (Hetherington, 2003; Vera \& Betz, 1992). From this point of view, relationships play a key role on the well-being of individuals (Perlman \& Vangelisti, 2006). Individuals enjoy getting into close relationships and expect to be satisfied with such close relationships throughout their lives. In this respect, it is known that the quality of a romantic relationship plays a key role in the psychological health of many individual and this quality obviously affects both the overall happiness and well-being of individuals (Demir, 2010; Lucas \& Dyrenforth, 2006; Whisman \& Baucom, 2012). Marriage may provide individuals with sexual satisfaction, love and passion, physical wellness, emotional support, loyalty, a stable and secure relationship and friendship. Marriage is supposed to fulfill a lot of expectations in social perception, and it is an institution that fulfills a lot of sexual, physical and psychological needs (Cox, 2006).

It is seen that how marriage is viewed is evolved over years in parallel with the nature, needs and purposes of human beings and marriage rates experience a decline worldwide (Regan, 2011). Global figures suggest that individuals continue to get married despite rising rate of divorce (Billeter, 2002), marriage age and co-habitation rates rather than marriage increase while reproduction rates tend to fall (Gottman, Murray, Swanson, Tyson, \& Swanson, 2002; Sungur, 2009). Increasing divorce rates in Turkey in parallel with the rest of the world imply that the individuals, couples and 
families who have the potential to raise psychologically healthy generations are on the decrease (Eskin, 2012). According to the 2015 data on the divorce rates of married couples in Turkey, while 602,982 individuals got married, 131,830 individuals divorced. It is remarkable that divorce rates have increased by 41 percent in the last 10 years (TÜIK, 2015). The changes in such figures suggest that marriage deserves a greater focus. Marital satisfaction both decreases divorce rates and allows couples to be in a close relationship in which they feel peaceful and well. Marital satisfaction and its relationship with different aspects of the partners' lives are frequently studied in the literature, and they continue to be a popular topic of study for marriage, family and couples therapists as well as researchers of this field (Jose \& Alfons, 2007). In universal terms, marital satisfaction is expressed as the measurement of the balance between the elements that are attributed positive connotations such as mutual interests, harmony, loyalty and those which are attributed negative connotations such as the idea of divorce, loneliness, complaints (McNamara \& Bahr, 1980). Marital satisfaction is not only based on what one of the partners want, expect or get from the marriage but is also shaped by the needs and capacity of the other partner, in addition to the environment in which the couples live (Levinger, 1970).

An extremely delicate and important topic as well as a popular field of study, marital satisfaction requires partners to accept each other, approve each other's behaviors, mutually dignify each other's identity and personality, express themselves to each other in an open, honest and deep sense of sharing, show affection and compassion to each other, showing regard to their emotional needs, offer social support to each other in several respects, and satisfy each other both emotionally and physiologically in terms of their sexual life (Jones, 1994; Nystul, 1999). Individuals may have a more satisfactory, successful or quality marriage for performing well in meeting all those needs of one another in a healthy marriage, which directly results in higher marital satisfaction rates. However, when partners fail to find a satisfactory response to those needs or enjoy the benefits that they expected of their marriage, their marital satisfaction declines in parallel (Stone \& Shackelford, 2007). Many studies suggest that it is very important for the partners to spend a sufficient and quality time together. One of the ways of deriving satisfaction from marriage is shaped by the level, rate and depth of the time spent by the partners and their mutual participation in such time, and it is seen that the individuals who mutually enjoy such time derive a greater satisfaction from their marriage (Sprecher, Metts, Burleson, Hatfield, \& Thompson, 1995).

Functionality of marriage is very important in life satisfaction, emotional wellbeing and quality of mental health (Reis \& Gable, 2003; Whisman \& Baucom, 2012). When close relations which have different effects on individuals' psychological health cause unfavorable results in the lives of individuals, declines or deteriorations may occur in the psychological health of individuals (Pateraki \& Roussi, 2013). 
Several studies and scientific data on the nature and functionality of marriage have attempted to shed light on the unknown aspects of marital satisfaction (Ampuero, 2014; Patrick, Sells, Giordano, \& Tollerud, 2007). Conceptualized as an individual's personal assessment of their spouse or relationship, marital satisfaction is a complex structure that is made up of numerous components (Ampuero, 2014; Fincham \& Linfield, 1997). They include many elements such as loyalty, commitment, economic independence, perceived equality in child care and household chores, common traits and interests of the partners, a fair distribution in the roles of the partners, the duration of pre-marital relationship, having a child or not, and socioeconomic status (Cox, 2006; Williams, Sawyer, \& Wahlstrom, 2012).

It is a common knowledge in the literature that marriage and the satisfaction derived from it have a great impact on the general well-being of individuals and their ability to live a good life. Among the concepts such as hope, creativity and stability that make the life of an individual more meaningful are concepts and structures such as engaging in a deep relationship, love, affection and marriage, which make an individual feel more valuable (Gillham \& Seligman, 1999). Studies on the well-being of married individuals have a long and rich history (Caughlin \& Huston, 2006). Individuals may have problems and difficulties in some time after they get married, such problems may be predictable and coping with such challenges allows both individuals and their relationships to grow and improve (Jourard, 1971). Functionality of close relationships and marriage is very important is very important on well-being, subjective well-being, overall life satisfaction, emotional well-being and psychological wellness (Reis \& Gable, 2003; Whisman \& Baucom, 2012). The need to start, develop and maintain deep and close relationships with other, which is one of the most important purposes of an individual's life is one of the key aspects of well-being. Relationships have functional aspects that may cause several apparent changes in the psychological state of individuals (Reis \& Gable, 2003). Therefore, since a satisfactory, successful and quality relationship is closely related to a strong psychological well-being, it continues to be a hot topic of research (Pateraki \& Roussi, 2013). In this respect, an examination of a good life reveals that in addition to a happy and satisfactory marriage, a sincere and deep self-disclosure, a strong communication and bonds of social support between the partners are essential.

Many interpersonal relationships are increasingly affected by social influence processes. Such social influence processes include verbal communication, body language, non-verbal communication, use of the physical environment and personal perceptions. In this network of relationships, individuals engage in relationships at different levels of intimacy such as having a spouse, significant other, mother, father, teacher, friend or neighbor, and the satisfaction that they derive from each relationship affects their level of happiness. Another element that highly affects the satisfaction 
derived from the network of relationship is self-disclosure which is a significant variable in this study. Self-disclosure involves one's disclosure of their emotions, attitudes and lifestyle to another individual (Altman \& Taylor, 1973). An individual's disclosure of their life fully and spontaneously removes the mystery between the individuals very fast (Jourard, 1971). As social beings, humans continuously express or convey information about them to others. Accordingly, an individual's sharing of their hopes, fears and disappointments with a trustworthy spouse may ensure that a deeper relationship develops compared to other relationships from which an individual may derive emotional satisfaction. Those who share stories about them with their partner and have a partner who will listen to their stories are on the way to being a good "match" and are able to move away from misunderstandings that may cause conflicts as their self-disclosing behaviors increase (Harvey \& Omarzu, 1999).

At this stage, success, satisfaction or happiness in relationships is not only about what individuals think or feel but also how they communicate with each other and other people (Nelson-Johns, 1999). Each individual has their own world and is expected to stretch out of this world and communicate with other people. Individuals can only make their vital foundations functional as beings that exist, think and communicate their thoughts (Cüceloğlu, 1994). One of the fundamental forms of this communication is the self-disclosure behavior (Morton, Alexander, \& Altman, 1976 as cited in Hendrick, 1981). Self-disclosure, which is defined as communication of oneself to others is not a one-time effort but a dynamic process, and a social behavior that continues throughout the life and the relationship, changes both individuals and relationships, thus making positive contributions to individuals' perception of social support and their sense of intimacy to their partner or other individuals with whom they engage in close relationships (Bak, Lin, \& Oh, 2014; Dindia, 2000). A two-way concept that both affects and gets affected by the variables of relationships (Hendrick, 1981), this social behavior is determined by the reactions of the partners in a marriage, and it is a structure that supports the self-esteem of an individual and makes them feel that their identity is approved (Greene, Derlega, \& Mathews, 2006). The affection or love between two individuals throughout their marriage may be about mutual self-disclosure. A strong and deep self-disclosure fosters love between the partners (Critelli \& Dupre, 1978). Self-disclosure adds depth to a relationship and contributes to the growth and development of the intimacy by enhancing the commitment in a relationship with a strong acceptance (Gilbert, 1976). Self-disclosure may reveal a great deal of information about the functionality of the communication skills between the partners and contributes to the satisfaction with a relationship (Millar and Millar, 1988). Self-disclosure increases with the level of intimacy in a relationship (Tolstedt and Stokes, 1994). In addition to its function as a cooperation whereby partners disclose their identity and accept each other's opinions and attitudes, intimacy allows the patterns of communication and interaction between two individuals, and it is 
very important for the partners to reveal their deeper emotions such as their desires, fantasies and concerns for each other in establishing this intimacy (Reis \& Shaver, 1988). In sum, one's disclosing themselves and responded by self-disclosure of their partner in a close, romantic relationship is a key predictor of satisfaction with a relationship in accordance with the principle that intimacy and interaction enhance communication (Laurenceau, Feldman Barrett, \& Pietromonaco, 1998).

There is a linear relation between self-disclosure in marriage and marital satisfaction (Jorgensen \& Gaudy, 1980; Levinger \& Senn, 1967; Millar \& Millar, 1988). Those individuals who believe that they have a positive communication with their partner are more satisfied with their relationship (Cupach \& Comstock, 1990; Gottman, Coan, Carrere, \& Swanson, 1998). An individual who discloses themselves to their spouse - a person that they choose - is able to perceive that their spouse responds by disclosing themselves, thus spouses become more familiar with each other and invest more in their relationship, support and improve it (Jourard, 1959). Selfdisclosure is one of the basic types of marital communication patterns, and plays an important role in marital stability and satisfaction (Derlega \& Chaikin, 1976; Gilbert, 1976). Married individuals disclose themselves less to their mother, father or their close friends of the same sex, and consider their spouse as the main source of selfdisclosure (Jourard \& Lasakow, 1958). Among the most common reasons for one's self-disclosure and communication of their lifestyle to their spouse are such potential benefits as emotional relaxation, the ability to find alternative solutions to problems and enhancing the interpersonal relationship between the partners (Burke, Weir, \& Harrison, 1976). Married individuals' willingness to communicate with their spouse for their personal problems helps marriage relationships be restored and enhanced, and improve the quality of marriage (Burke et al., 1976). This improvement in quality and establishing the functionality of marriage require a high rate of self-disclosure, naturalness and openness between the partners (Waring, 1981). Thus, particularly a positive reward and mutual self-disclosure of partners are preconditions of marital satisfaction of the spouses (Barnes, Schumm, Jurich, \& Bollman, 1984).

Another element that highly affects the satisfaction of individuals with their relationship networks is the spousal support, which is another main variable of this study and is categorized under the title of social support. Social support includes the frequency and power of the resources that an individual receives personally from their relationships with others. Social support contains different resources, emerges from personal needs, differs among individuals in terms of expression, is in different types and directions and difficult to measure (Sarason \& Sarason, 2009). It has different definitions (Rivero, 2012). Social support, i.e. support or assistance to cope, is conceptualized as a structure that makes active contributions to the effort of an individual to cope with stress (Thoits, 1986). In addition to its status as an 
important protecting factor for both physiological health and overall well-being and psychological health of an individual according to many theories (Rini \& DunkelSchetter, 2010; Uchino, 2004), social support protects individuals from mental and physical powers of negative life events and particularly the high level of social support offered by the spouse in a marriage provides strength in coping with stressful life events including economic hardships, diseases, depression, work-related issues and transition to parenthood (Fletcher, Simpson, Campbell, \& Overall, 2013).

Throughout the life of an individual at almost any age, an individual feels happiest and most useful when they know that they have a dependable individual in their relationship during the times of hardships in particular (Nelson-Johns, 1999). Family and friends are the most powerful and dynamic sources of social support throughout the life. Particularly long-term friendships prove a remarkable source of emotional and social support due to an intimacy and familiarity brought by a common background, and contributes to supporting the mutual well-being of individuals and developing a positive identity (Siebert, Mutran, \& Reitzes, 1999). In addition, it is seen that individuals in an emotionally satisfying relationship are able to remain stronger in the face of stressful and difficult life events and even if they are not able to derive social support from other sources, they have a more stable psychological state because of spousal support (Brown, Orbuch, \& Maharaj, 2010). One of the key roles in functionality of marriage is the exchange of social support among the partners. For this reason, it is important to know in clinical terms how this interpersonal element affects a marriage (Dehle, Larsen, \& Landers, 2001). A sufficient level of social support between the partners in a marriage is an indication that they have a higher well-being than other individuals in both physiological and psychological terms. This shows that there is a strong and positive relationship between social support and marriage (Acitelli \& Antonucci, 1994; Stone \& Shackelford, 2007).

A considerable amount of information available in literature about social support suggests that it is the support offered by the spouse who is the first point of reference particularly in case of need that has a critical role in actively coping with the life challenges (Brock \& Lawrence, 2010; Coyne \& DeLongis, 1986; Mossakowski \& Zhang, 2014; Sullivan \& Davilla, 2010; Wallace \& Jovanovic, 2011). The social support with a strong emotional side received by an individual at this point is one of the key predictors of their well-being (Biehle \& Mickelson, 2012). The importance of this exchange of support between the spouses in fulfilling their psychological needs and their needs for affection plays an important role in increasing this well-being (Canbulat \& Cihangir Çankaya, 2014). In this respect, there is a growing number of studies that highlight the importance of spousal support in relational well-being. How partners help each other cope with their personal problems, stress and other life challenges and duties, and how this affects the relational satisfaction is studied in the 
literature (Sullivan \& Davilla, 2010). It is important in the progress of a marriage for the spouses to know what their spouse need and when, and to discover what to do and take action. A number of studies confirm this, and show that partners' support to each other with coping with personal challenges and the social support that they offer to each other every day play a central part in the functionality of marriage (Verhofstadt, Ickes, \& Buysse, 2010). While positive support of the partner has significant effect on the life of an individual, insufficient support from the partner exposes an individual to negative effects (Trackey, 2014). In addition, partners' talking about their perceived support from each other can improve the quality of communication and marriage in general terms (Russell \& Wells, 1994). While offering support to the partner in a difficulty is beneficial for their well-being, the effectiveness of support becomes solid when an individual is able to perceive the support offered by their partner (Knoll, Kienle, Bauer, Prüller, \& Luszczynska, 2007).

The support of a sensitive partner reinforces love and affection, and alleviates conflicts. This may be caused by an increase in supporting gestures. Thus, the relationship between the partners get stronger and conflicts can be prevented (Jensen, Rauer, \& Volling, 2013). If partners perceive a sufficient level of support during this exchange of social support, they are able to access the resources required to cope with life challenges and strengthen their adaptability. In parallel with this, those individuals who have a satisfactory and supporting marriage achieve strong marriages (Williams, 2003). Marriage provides a similar amount of social support for women and men (Wallace \& Jovanovic, 2011) but while men improve their positive sentiments with the instrumental support from their wife, women rather tend to reduce their negative sentiments by the instrumental support that they believe that they offer to their husband (Knoll et al., 2007). It is beyond any doubt that regardless of their gender, partners enjoy valuable and significant contributions for having a supporting partner particularly when life events tend to become challenging. Furthermore, it is important for the quality of close relationships to provide appropriate support and feedback to each other not only during the challenges of life but also when their life goes favorably (Gable \& Algoe, 2010).

While individuals who are supported by their partner tend to be less depressive when they encounter a problem in their marriage, less spousal support increases their tendency to get depressed (Horwitz, McLaughlin, \& Raskin White, 1998). A sufficient level of perceived partner support is significantly related to the symptoms of depression and perceived levels of stress. Accordingly, it is seen that those individuals who perceive a sufficient level of support from their partner tend to present fewer symptoms of depression and perceive the stress factors in their life more manageable and controllable (Dehle et al., 2001). While the life events of married individuals continue, the partner that offers the social support should also have a certain degree of awareness. 
The partner that will offer social support should discover the stressful condition of their partner, distinguish the assistance that their partner needs, figure out what kind of social support would help their partner more effectively, decide personally whether they would be able to provide such support to their partner, and show their supporting behavior when they feel that they are motivated enough to take action (Regan, 2011).

How marriage is perceived by the partners affects many psychological and physical health outputs of individuals, and it is important for the literature to examine the ability to adapt to the marriage life since it has such an effective mechanism (Koydemir, Sun Selışık, \& Tezer, 2008). Studying such an important structure is very crucial and necessary to see the functioning of the process more clearly and increase the happiness and satisfaction in life (Yetim, 2001). Moreover, although several studies have discussed marital satisfaction, the factors that increase this satisfaction have not been clearly established so far. Particularly there is no clear structure as to what spouses focus on while making a subjective decision about their marital satisfaction. It is also important to clearly establish how women and men differ from each other in evaluating their relationship or what their bases of evaluation are, and what factors make a marriage satisfactory (Nielsen, 2005). Unlike previous literature on marital satisfaction, the present study attempts to discuss and explain marital satisfaction based on more positive concepts. While the effects of rather negative concepts such as depressive symptoms, anxiety and physical health on marital satisfaction have been frequently addressed in the literature, this study tests a model based on positive structure taking into account all conceptual structures and predictors such as perceived social support and spousal self-disclosure and the perspective of positive psychology. Moreover, the Turkish literature on the subject lacks studies that examine the place and effect of self-disclosure particularly in close relationships. Since this is considered a gap in the literature, selfdisclosure to spouse was discussed as one of the main variables of the present study. In addition, in the light of the said literature, it has become necessary to design a comprehensive model about how multiple models affect, and are related to, marital satisfaction and to test that model. The literature related to the present study attempts to design a map of quality marriages based on a study of several subjects including what the common characteristics of more happy and successful marriages in recent years might be, how satisfactory marriages can be achieved, and what factors have a positive affect on harmonious marriages. It is seen that a lot of studies involve a rather basic level of research such as what elements explain, predict and affect marital satisfaction. On the other hand, this study is intended to provide a clearer and distinct picture of the predictors of marital satisfaction by a method of analysis that helps this study reveal the relations among the variables free from errors so that marital satisfaction is addressed from a larger point of view. Based on the information provided above, it is seen that especially the foreign literature distinctly addresses the effect of the variables of selfdisclosure to spouse and spousal support on marriage. In the light of this information, 
the study investigates the effects of such individuals on Turkish culture, and for this purpose, the relations among such variables are conceptualized by structural equation modeling based on a comprehensive analysis. In this context, the full mediator role of the self-disclosure variable in the relationship between marital satisfaction and spousal support is tested by a model test. This study is important for understanding the concept of marital satisfaction that is important for bilateral relationships and materializing it in the social and cultural structure of Turkey. It is thought that addressing and examining the concept of marital satisfaction by a structural model may contribute to presenting the relationship between this concept and other independent variables.

\section{Method}

In this study, a relational research pattern was used to study the relationship among marital satisfaction, spousal support and spousal self-disclosure. A structural equation model was used to test the power of the variables of spousal support and spousal selfdisclosure as a predictor of marital satisfaction.

\section{Participants}

The study tested statistical significance of the model that was suggested under the study based on the data collected from 549 married couples in the model test. The participant group of the study were made up of volunteers who lived in Ankara, had a wage-earning job, and who were at least high-school graduates. An appropriate sampling among non-random sampling methods was used in the study. Before the research data were collected, necessary permits were obtained from the boards of ethics of two state universities. The application forms of the study were completed in person by the participant group in the form of pencil-and-paper tests. The data of the present study were collected by implementing scales in the workplaces of married individuals on business days and at office hours with their consent taken. The data were collected on the basis of voluntariness and confidentiality. The participants were given "Informed Consent Forms" that explained the purpose of the study in advance. Then, the application forms were handed to the individuals who volunteered to take part in the study in closed envelopes, and also received back in closed envelopes after they were completed. The details of the participants are given in Table 1.

\section{Data Collection Tools}

Three different measurement tools were used to collect data in the study. The study used the "Marriage Life Scale" designed by Tezer (1986) to determine the level of marital satisfaction, the dependent variable of the study; the "Spousal Support Scale" designed by Yildırım (2004) to determine the level of spousal support, one of the independent variables of the study; and the "Scale of Self-Disclosure to Spouse" 
Table 1

Demographics of the Participants

\begin{tabular}{|c|c|c|c|}
\hline \multicolumn{2}{|l|}{ Variable } & \multirow{2}{*}{$\frac{\mathrm{n}}{276}$} & \multirow{2}{*}{$\begin{array}{c}\% \\
50.3\end{array}$} \\
\hline & Female & & \\
\hline Sex & Male & 273 & 49.7 \\
\hline \multirow{3}{*}{ Educational Background } & High School & 106 & 19.3 \\
\hline & University/Higher Education & 327 & 59.6 \\
\hline & Master/PhD & 116 & 21.1 \\
\hline \multirow{10}{*}{ Occupation } & Public Employee & 158 & 28.8 \\
\hline & Engineer & 77 & 14.0 \\
\hline & Worker & 49 & 8.9 \\
\hline & Bank Employee/Economist & 42 & 7.7 \\
\hline & Scholar & 39 & 7.1 \\
\hline & Teacher & 35 & 6.4 \\
\hline & Self-employed & 26 & 4.7 \\
\hline & Physician/Nurse/Healthcare Professional & 11 & 2.0 \\
\hline & Judge/Prosecutor/Lawyer & 10 & 1.8 \\
\hline & Other & 102 & 18.6 \\
\hline \multirow{3}{*}{ Contribution to Income } & Female & 92 & 16.8 \\
\hline & Male & 426 & 77.6 \\
\hline & Equal & 29 & 5.3 \\
\hline \multirow{3}{*}{ Type of Wedding } & Companionate & 426 & 78.0 \\
\hline & Arranged & 114 & 20.9 \\
\hline & Other & 6 & 1.1 \\
\hline \multirow{4}{*}{ Pre-marriage Relationship Time } & Less than a year & 123 & 22.4 \\
\hline & $1-5$ year(s) & 308 & 56.1 \\
\hline & $6-10$ years & 57 & 10.4 \\
\hline & Not specified & 61 & 11.1 \\
\hline \multirow{6}{*}{ Married Time } & Less than a year & 30 & 5.5 \\
\hline & $1-5$ years & 138 & 25.1 \\
\hline & $6-10$ years & 100 & 18.2 \\
\hline & $11-15$ years & 59 & 10.7 \\
\hline & $16-20$ years & 70 & 12.8 \\
\hline & 21 years or more & 152 & 27.7 \\
\hline \multirow{2}{*}{ Children } & Yes & 438 & 78.6 \\
\hline & No & 111 & 21.4 \\
\hline \multirow{4}{*}{ Number of children } & 1 & 198 & 45.2 \\
\hline & 2 & 205 & 46.8 \\
\hline & 3 & 32 & 7.3 \\
\hline & 4 & 3 & 0.7 \\
\hline
\end{tabular}

designed by Çağ and Yıldırım (2017) to measure the level of spousal self-disclosure, the other independent variable of the study.

The Marriage Life Scale (MLS). The highest possible score is 50 and the lowest 10 in the 10-item, 5-point ("Strongly Disagree", "Disagree", "Not Sure", "Agree", "Strongly Agree"), Likert-type MLS that measures the overall marital satisfaction. The scale was applied to married and divorced individuals to test the criterion-related validity of the scale, and a significant difference was found between the average 
scores of the groups $(t=6.23, p<0.01)$. A comparison was made with the scores of the Social Behavior Questionnaire, which measures social appreciation, as a proof of the indirect validity of the scale. The results of the MLS showed that individuals were little affected by social appreciation tendencies $(r=0.21)$. The reliability coefficient determined by the test-retest method was 0.85 , Cronbach Alpha internal consistency coefficient was 0.88 for the male group and 0.91 for the female group (Tezer, 1986). In addition, the Cronbach Alpha reliability coefficient of the scale was calculated based on the data collected for the model test under the present study and the Cronbach Alpha reliability coefficient of the MLS was found .93.

The Scale of Spousal Self-disclosure (SSSD). Primarily the scales in the literature were studied in the development stage of the SSSD that was designed by Çağ and Yildırım (2017). Especially the scales in the foreign literature which were designed to measure the concept of self-disclosure were studied at this stage (Cayanus \& Martin, 2004; Derlega, Winstead, \& Greene, 2007; Rubin, Hill, Peplau, \& Dunkel-Schetter, 1980; Waring et al., 1998). Using the scales in the literature and the theories on selfdisclosure, a pool of 92 items was prepared. The items selected from this pool were used to create the first version of the scale. Opinions were taken from five specialists of Psychological Counseling and Guidance who were well-informed about the subject to assess clarity of the language and expressions of this experimental version and test the validity of its scope. After the feedbacks received from the specialist group were applied to the scale, the preliminary implementation of the study was performed on 25 married individuals ( 17 female, 8 male) for assessment of the scale for ease of responding and clarity. The scale was finalized per feedbacks of the said married individuals and made ready for implementation. In the light of these efforts, the trial form of the 64-item scale was formed. The trial form of the 64-item scale was implemented to 468 married individuals for an exploratory factor analysis. Following the exploratory factor analysis, further data collected from 346 married individuals were analyzed to test the emerging structure of the scale (Çağ \& Yıldırım, 2017).

It was found upon the exploratory factor analysis that the items in the scale were distributed on three factors: Nature of the Relationship, Awareness and Opennes. A 29-item form emerged after certain items were eliminated on the basis of items overlapping on multiple factors, items where the total correlation values were lower than .20, and the principle that at least 3 items should be available for each factor. A confirmatory factor analysis was applied to the 29-item structure of the SSSD distributed to 3 factors found by AFA. Thus, the factor structure of the SSSD designed under the present study with three independent sub-factors and five assessment points were tested by a primary and secondary level confirmatory factor analyses. The KMO (Kaiser-Meiyer-Olkin) coefficient of this 5-point ("Absolutely Like Me", "Like Me", "Partly Like Me", "Not Like Me", "Not Like Me at All") Likert scale was 95 and the 
Barlett Sphericity Test was significant. The SSSD has three factors with an eigenvalue greater than 1 . While the first factor alone explains $40.75 \%$ of the explained variance, the three factors together explain $53.23 \%$ of the explained variance. The factor loads of the items varied between .50 and .80 . Following the varimax rotation method, the first factor, "nature of the relationship", consisted of 14 items; the second factor, "awareness", consisted of 10 items; and the third factor, "openness", consisted of 5 items. Accordingly, an examination of the primary confirmatory factor analysis results where this three-factor structure of the scale was tested reveals that the values of $\chi 2 / \mathrm{sd}=2.89 \leq 3 ; \mathrm{NFI}=.96, \mathrm{NNFI}=.97$ and $\mathrm{CFI}=.97 \geq .95$ enable the scale to fulfill the perfect concordance value with respect to all concordance values ( $\mathrm{Hu}$ \& Bentler, 1999; Hooper, Coughlan, \& Mullen, 2008). Similarly, SRMR $=.06 \leq$ .08 is between the perfect concordance values (Hu \& Bentler, 1999). As a result of DFA, the $\chi 2$ sd ratio, and RMSEA, RMR / SRMR, CFI, NFI and NNFI indices were assessed, and it was found that all indices were sufficient for the model concordance. As a result, the scale structure was found to be confirmed (Çağ \& Yıldırım, 2017).

Thus the final form of this 29 -item scale with 7 reverse items and 3 factors, namely the nature of the relationship, awareness and openness, was achieved to measure the self-disclosure behavior between spouses. It was found upon the present study that the scale had sufficient psychometric properties. A 5-point Likert scale was used to measure the quality that each item in the scale stands for. 29 items in the final form are scored between " $1=$ Not Like Me at All" and " $5=$ Absolutely Like Me". The scale contains 7 reverse items. A total score is calculated by the scale. The lowest possible score is 29 , and the highest 145 . A higher score indicates a higher level of self-disclosure for a married individual (Çă̆ \& Yıldırım, 2017).

Furthermore, the SSSD showed a negatively significant correlation with the Dyadic Trust Scale (DTS) $(r=-.60)$. The validity findings show that this scale is capable of measuring the self-disclosure levels of spouses. In addition, the reliability of the SSSD was calculated by two methods. First, a Cronbach Alpha coefficient was calculated $(\alpha=.95)$; second, split-half test method was calculated $(r=.93)$. The reliability coefficients indicate that the SSSD is a scale that can be used to measure spousal self-disclosure (Çağ \& Yıldırım, 2017).

Spousal Support Scale (SSS). Designed to measure spouses' perceived support from each other, SSS is a 23-item, 3-point ("Like Me", "Partially Like Me", Not Like Me") Likert scale. SSS was tested for validity using factor analysis and similar scales. The SSS had a KMO (Kaiser-Meiyer-Olkin) coefficient of .95 and a significant Barlett Sphericity Test. The common factor variance of the factors on each variable varies between .40 and .73. The SSS has four factors with an eigenvalue greater than 1 . While the first factor alone explains $44.86 \%$ of the explained variance, the 
four factors together explain $58.40 \%$ of the explained variance. The factor loads of the items varied between .46 and .84 . It was seen that the first factor, "Emotional support" had 9 items, the second factor "Material aid and knowledge support" had 7 items, the third factor, "Appreciation support" had 8 items, and the last factor, "Social interest" had 3 items. The scale had 3 reversed items which were scored in reverse. The highest possible score was 81 , and the lowest 27. A higher score indicates a higher perceived spousal support (Yildırım, 2004).

For comparison of the SSS with similar scales for validity, its correlation with the Beck Depression Scale was calculated, and a negatively significant correlation was found between the two scales $(r=-.27)$. The validity findings show that this scale is capable of measuring the support that spouses receive from each other. In addition, the reliability of the SSS was calculated by two methods. First, the Cronbach Alpha coefficient was calculated $(\alpha=.95)$. Second, the test-retest reliability coefficient was calculated $(r=.89)$. The reliability coefficients show that the SSS can reliably be used to measure the support that spouses receive from each other (Yildirım, 2004). In addition, the Cronbach Alpha reliability coefficient of the scale was calculated based on the data collected for the model test under the present study and the Cronbach Alpha reliability coefficient of the SSS was found .96.

Personal Information Form (PIF). PIF was prepared by the researcher to collect information about the socio-demographic qualities of married individuals. The form contains items that reveal sex, age, educational background, employment, job satisfaction, monthly household income, contribution to monthly household income, duration of pre-marriage relationship, the age of marriage, the year of marriage, the number of previous marriages, and the number of children.

\section{Data Collection Period}

The required permits were obtained from the university boards of ethics (Middle East Technical University and Hacettepe University) before the collection of the research data. The data of the work group of the study were collected by implementing scales in the workplaces of married individuals on business days and at office hours with their consent taken.

The data were collected on the basis of voluntariness and confidentiality. The participants were given "Informed Consent Forms" that explained the purpose of the study in advance. Then, the application forms were handed to the individuals who volunteered to take part in the study in closed envelopes, and also received back in closed envelopes after they were completed.

It took approximately 20 minutes for the work group reached for a model test under the study to complete the application form which contained all data collection 
instruments. Data were collected from 610 married individuals. Then the data of 61 individuals were removed for incomplete or erroneous filling of the forms, and the data obtained from the remaining 549 married individuals were analyzed.

\section{Data Analysis}

LISREL 8.8 was used to analyze the measurement and the structural model, test the mediator model and test the direct effects at the stage of model testing of the research, and AMOS 20 was used to find the statistical significance levels of the indirect effects and mediator effects.

One of the data analysis methods that are frequently used in social sciences, the Structural Equation Model (SEM) is an effective model testing and development method that can reveal the causality among the variables within the hypotheses established by the author and allows the models based on the literature to be tested within the entire structure (Çelik \& Yılmaz, 2016).

In this study, SEM was used to test the model designed for marital satisfaction. The direct, indirect and mediator effects of the predictive variables on the predicted variable were analyzed in the study. In this respect, spousal support and self-disclosure were identified as the predictor variables of the study. The predicted variable of the study was marital satisfaction. The relations between the said predictor and predicted variables of the study were analyzed using SEM. The mediation role of spousal selfdisclosure in the relationship between marital satisfaction and spousal support was tested by mediator modeling.

Certain concordance coefficients should be taken into consideration to test the acceptability of the SEM. In this context, multiple concordance coefficients as well as acceptable and perfect concordance values for such concordance coefficients are given in Table 2.

Table 2

Concordance Values for the Confirmatory Measurement Model*

\begin{tabular}{lcc}
\hline & Perfect Concordance & Acceptable Concordance \\
\hline $\mathrm{c}^{2} / \mathrm{sd}$ & $0 \leq \boldsymbol{c}^{2} / \mathrm{sd} \leq 2$ & $2 \leq \boldsymbol{c}^{2} / \mathrm{sd} \leq 3$ \\
$\mathrm{RMSEA}$ & $0 \leq \mathrm{RMSEA} \leq 0.05$ & $0.05 \leq \mathrm{RMSEA} \leq 0.08$ \\
$\mathrm{RMR}$ & $0 \leq \mathrm{RMR} \leq .05$ & $0.05 \leq \mathrm{RMR} \leq .08$ \\
$\mathrm{SRMR}$ & $0 \leq \mathrm{SRMR} \leq 0.05$ & $0.05 \leq \mathrm{SRMR} \leq 0.08$ \\
$\mathrm{NFI}$ & $0.95 \leq \mathrm{NFI} \leq 1.00$ & $0.90 \leq \mathrm{NFI} \leq 0.95$ \\
$\mathrm{NNFI}$ & $0.95 \leq \mathrm{NNFI} \leq 1.00$ & $0.90 \leq \mathrm{NNFI} \leq 0.95$ \\
$\mathrm{CFI}$ & $0.95 \leq \mathrm{CFI} \leq 1.00$ & $0.90 \leq \mathrm{CFI} \leq 0.95$ \\
GFI & $0.90 \leq \mathrm{GFI} \geq 1.00$ & $0.85 \leq \mathrm{GFI} \leq 0.90$ \\
$\mathrm{AGFI}$ & $0.90 \leq \mathrm{AGFI} \geq 1.00$ & $0.90 \leq \mathrm{AGFI} \geq 1.00$ \\
\hline
\end{tabular}

*(Hu \& Bentler, 1999; Schumacher \& Lomax, 2004; Kline, 2011). 
Different researchers accept different ranges for acceptable, good and perfect concordance coefficients of the SEM. The ranges given in the Table 2 were considered in the present study.

SEM is a parametric test, and variables of SEM has to fulfill the normality and homogeneity which are the fundamental conditions of parametric tests. In this respect, normality analyses were reviewed for each variable, and the values of the findings are given below.

In this section, before proceeding to the SEM, the stages of the process of testing the assumptions of missing values, extreme values, normality, multiple dependency, linearity and confirmatory measurement model and preparing the data ready for the SEM analysis are presented.

\section{a. Missing Values}

The data collected from the participants were subjected to a missing values analysis, and it was seen that this rate is below 5 percent. So, no observation was excluded from the analysis.

\section{b. Extreme Values}

Multidirectional extreme values in the dataset were analyzed using the Mahalanobis distances within the Regression (Çokluk, Şekercioğlu, \& Büyüköztürk, 2010). For this purpose, the Mahalanobis, Cook's and Leverage values of the dataset were reviewed, the data of 32 participants contained extreme values that would upset the normality of the study, and were decided to be removed from the dataset.

\section{c. Normality}

First, the histogram graphs for the variables of marital satisfaction, spousal support and self-disclosure were examined individually, and then the normality of the data set was checked. In this respect, the bell curves derived from the histograms were considered an indication of normality. In addition to histograms, the descriptive values as well as kurtosis and skewness values of the data set were examined and it was seen that the conditions required for normality were fulfilled for each variable. Lastly, a normality analysis used in large samples to test normality, Kolmogorov-Smirnov test was run and it was found that the dataset showed a normal distribution for each of the variables of marital satisfaction, spousal support and spousal self-disclosure. 
Table 3

Findings of the Normality Test for All Variables

\begin{tabular}{lcccccc}
\hline & $n$ & $\bar{x}$ & Median & Mod & Skewness & Kurtosis \\
\hline Marital Satisfaction & 549 & 38.30 & 40 & 39.75 & -.85 & -.15 \\
Spousal Support & 549 & 67.84 & 70 & 68.55 & .05 & -.89 \\
Self-disclosure to Spouse & 549 & 108.46 & 110 & 108.98 & .13 & -.53 \\
\hline
\end{tabular}

An examination of Table 3 reveals that mod, median and arithmetic means are very close to each other for the variables of marriage satisfaction, spousal support and spousal self-disclosure, the dataset has acceptable kurtosis and skewness values and no extreme values. In a standard distribution, kurtosis and skewness coefficients are expected to be zero. A kurtosis and skewness of -1 to +1 is considered an indication that distribution does not show a remarkable deviation from the normal (Mertler \& Vannatta, 2005). When the dataset is considered from the perspective of such criteria, the variables in the study can be said to show a normal distribution. Accordingly, the findings were interpreted such that the dataset for marital satisfaction, spousal support and spousal self-disclosure shows a normal enough distribution for the SEM. The descriptive statistics about the variables in the model are given in the Table 4.

Table 4

Descriptive Statistical Findings of Variables

\begin{tabular}{lccccc}
\hline & $n$ & $\min$ & $\max$ & $\bar{x}$ & sS \\
\hline Marital Satisfaction & 549 & 10 & 50 & 38.30 & 8.42 \\
Spousal Support & 549 & 31 & 81 & 67.84 & 11.89 \\
Self-disclosure to Spouse & 549 & 44 & 145 & 108.46 & 20.33 \\
\hline
\end{tabular}

As can be seen in the Table 4, minimum and maximum values of the variables of marital satisfaction $(\bar{x}=38.30$, ss $=8.42)$; spousal support $(\bar{x}=67.84$, ss $=11.89)$ and spousal self-disclosure $(\bar{x}=108.46, s s=20.33)$ in the model are in the expected range.

\section{d. Multiple Dependency}

Before testing the model, correlation coefficients, VIF and tolerance values among the variables were calculated for a multiple dependency assumption. First, the correlation values among the variables were tested. According to this, as can be seen in the Table 5, the highest correlation coefficient was .84 which was between the variables of spousal self-disclosure and marital satisfaction. The lowest correlation coefficient was .79 which was between the variables of spousal support and marital satisfaction.

Table 5

Correlation Coefficients among the Variables

\begin{tabular}{lccc}
\hline & 1 & 2 & 3 \\
\hline 1. Marital Satisfaction & 1 & & \\
2. Spousal Support & .79 & 1 & 1 \\
3. Self-disclosure to Spouse & .84 & .81 & 1 \\
\hline
\end{tabular}


The correlation coefficients between the variables in the model specified in Table 5 were examined on the basis of the multiple-dependency limit values. According to Zainodin and Yap (2013), .95 can be considered lower limit for multiple dependency. In addition, according to the general perception, the correlations between .00 and .30 may indicate a "low" correlation, .31 and .70 a "medium" correlation, and .71 and above a "high" correlation (Büyüköztürk, 2006). However, it is possible to talk about a multiple dependency problem at the level of $r>.90$ (Çokluk et al., 2010). Moreover, according to Kline (2005), a correlation above .85 among the variables point to a multiple dependency. When the dataset is examined based on this information, it is fair to say that the assumption of multiple dependency is fulfilled.

In addition to the correlation values among the variables, Variance Inflation Factors (VIF) and tolerance values are taken into account to test the multiple dependency assumption. It is expected that the tolerance value will not be lower than .20 , and VIF will not be higher than 5 (Menard, 1995). In addition, VIF values smaller than 10 and tolerance values smaller than 30 means the absence of a multiple dependency problem (Çokluk et al., 2010). In this study, the reference values given by Çokluk et al. (2010) were taken into consideration. Accordingly, it was seen that VIF values of the independent variables, 2.99 and 3.14, were fairly below 10, and the tolerance values were below 30 . In line with these findings, one can say that there is a multiple dependency problem among the independent variables in the model.

\section{e. Linearity}

The assumption of linearity was also tested before testing the model. Scatter diagrams were examined to test the assumption of linearity. Accordingly, it was found that the linearity assumption of the model dataset was fulfilled.

\section{f. Confirmatory Measurement Model}

The structure of the confirmatory measurement model for the variables of marital satisfaction, spousal support and spousal self-disclosure was also tested before the model was tested. For this reason, DFA was performed to analyze the joint concordance indices of all variables. It was seen that the findings of the confirmatory measurement model and the model concordance coefficients of such findings $(c 2 / s d$ $=0.29, R M S E A=.071)$ were satisfactory.

\section{Results}

The following sub-hypotheses were tested under the study hypothesis that "Spousal self-disclosure has a statistically significant role in the correlation between spousal support and marital satisfaction": 
1. Spousal support is a significant predictor of marital satisfaction.

2. Spousal self-disclosure is a significant predictor of marital satisfaction.

3. Spousal self-disclosure has a mediator role in the relationship between spousal self-disclosure, spousal support and marital satisfaction.

Among the findings of the model whereby the spousal self-disclosure variable mediates the correlation between the variables of spousal support and marital satisfaction, firstly the predictor relationships between spousal support and marital satisfaction were examined and the findings were given in Figure 1.

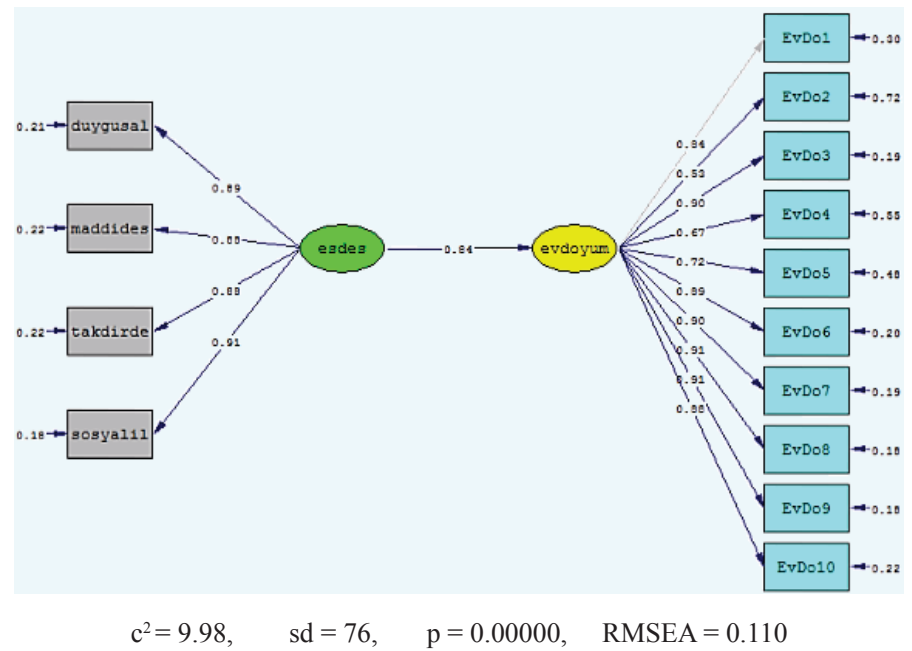

* emotional: Emotional support, material: Material aid and knowledge support, apprecia: Appreciative support, socialin: Social interest

Figure 1. Predictor relationships between spousal support and marital satisfaction.

The concordance coefficients for the structural model where the predictor relationship between the spousal support and marital satisfaction is examined in Figure 1 are given in Table 6.

Table 6

Multiple Concordance Coefficients for the MOdel

\begin{tabular}{lccccccccc}
\hline Model & $c^{2} / s d$ & $N N F I$ & NFI & IFI & RFI & CFI & RMSEA & GFI & AGFI \\
\hline YEM & 7.63 & .92 & .94 & .88 & .88 & .89 & .110 & .84 & .82 \\
Criteria & $\leq 3$ & $\geq .90$ & $\geq .90$ & $\geq .90$ & $\geq .90$ & $\geq .95$ & $\leq .80$ & $\geq .85$ & $\geq .85$ \\
\hline
\end{tabular}

An examination of the path diagram and multiple concordance coefficients revealed that the model designed for prediction of marital satisfaction by spousal support did not yield good concordance. Therefore, it was decided that the variable of spousal self-disclosure be included in the model and indirect relationships in the model be tested. Accordingly, the variable of spousal self-disclosure was added to the 
model, and coefficients of the potential indirect relationships were examined with the hypothesis that "Spousal self-disclosure has a statistically significant mediator role in the relationship between spousal support and marital satisfaction." The findings of this tested model are given in the Figure 2.

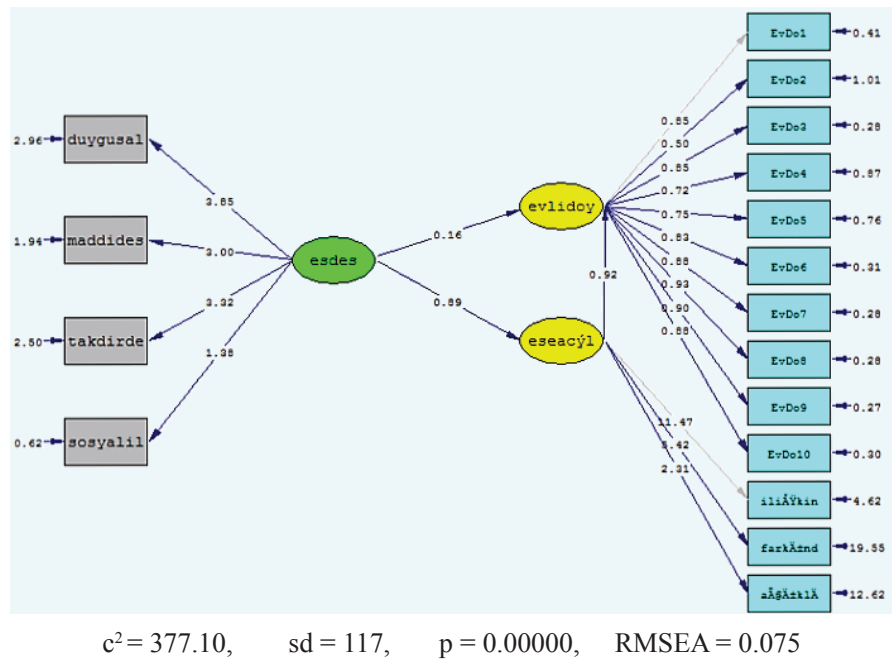

Figure 2. Predictor relationships between spousal support and marital satisfaction.

When Figure 2 is examined, it is seen that the model established among spousal support, spousal self-disclosure and marital satisfaction yields a good concordance. The purpose of the third model is to find out whether spousal self-disclosure has a mediator effect between spousal support and marital satisfaction. It is necessary to consider the prediction coefficient between the variables of spousal support and marital satisfaction given in Figure 1 to establish the mediator role of the variable of spousal self-disclosure. An examination of the values given in Figure 1 reveals that the prediction coefficient between spousal support and marital satisfaction is .84. On the other hand, it is seen that the prediction coefficient between spousal support and marital satisfaction falls to .16 in Figure 2. In the mediator relation, the predictor coefficient determined between two variables is expected to drop or become insignificant after the mediator variable is added (Şimşek, 2007). While a loss of significance of this predictor coefficient after the variable and an apparent drop in the prediction coefficient point to full mediation, notso-apparent drops in the prediction coefficient and a maintained statistical significance in the direct relationship among variables point to partial mediation (Koopman, Howe, Hollenbeck, \& Sin, 2015). In this respect, when Figure 1 and Figure 2 are examined, it is seen that the prediction coefficient of .84 between spousal support and marital satisfaction dropped to .16. Therefore, this finding implies that spousal self-disclosure may have a full mediator role in the predictor relationship between the spousal support and marital satisfaction. Based on this finding, the mediation effect was tested by another hypothesis in the mediator relationship that "Spousal self-disclosure has a full 
mediator role in the relationship between spousal support and marital satisfaction." At this stage, the direct predictor relationships between spousal support and marriage satisfaction were removed and the findings of the SEM that tested the full mediator role of spousal self-disclosure are given in Figure 3.

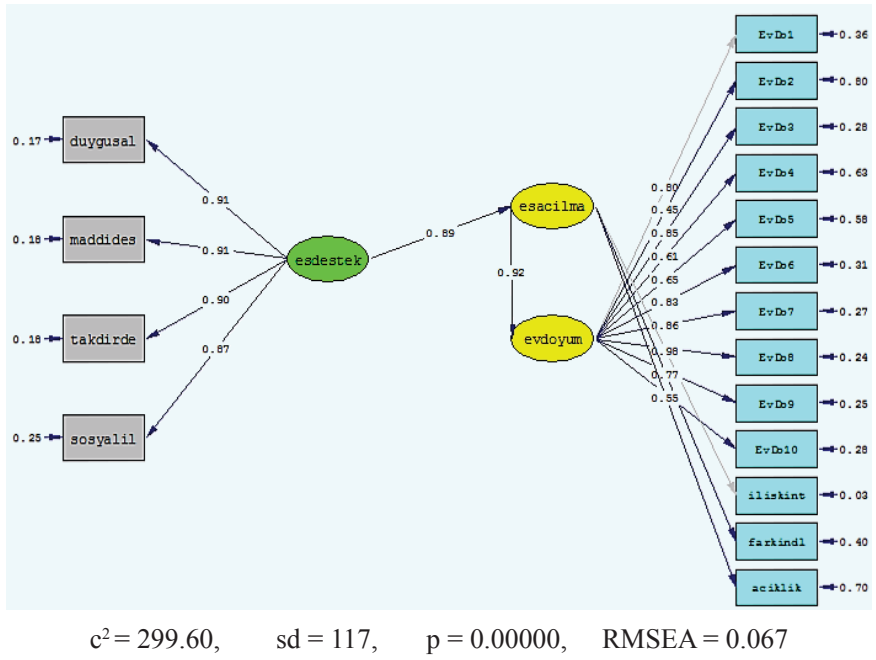

Figure 3. Structural equation model of the full mediator role of spousal self-disclosure.

An examination of Figure 3 reveals that the variable of spousal self-disclosure has a full mediator role between spousal support and marital satisfaction. In order to find out the concordance among the variables in the model, $t$ values were analyzed and the findings are given in Figure 4.

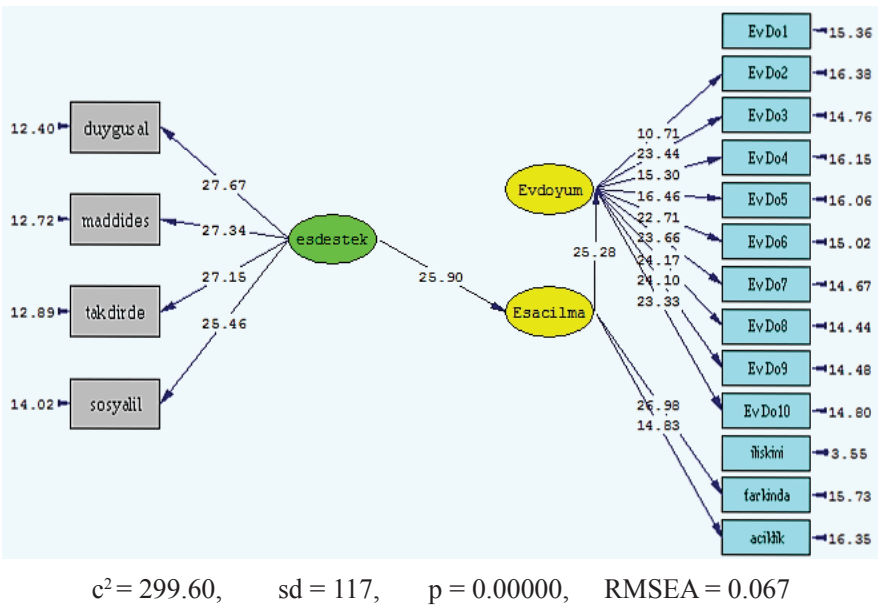

Figure 4. The path diagram showing the $t$ values of the full mediator model.

Figure 4 reveals that there is not a discordant variable among the observed and implicit structures of the variables that form the full mediator model with all variables 
having a $t$ value above 1.96. Those findings show a good concordance between the implicit and observed variables that form the model. The multiple concordance coefficients with regard to the full mediator model are given in Table 7.

Table 7

Multiple Concordance Coefficients for the Mediator Model

\begin{tabular}{lcccccccccc}
\hline Model & $c^{2} / s d$ & NNFI & NFI & IFI & RFI & CFI & RMSEA & SRMR & GFI & AGFI \\
\hline YEM & 2.56 & .98 & .98 & .99 & .98 & .99 & .067 & .037 & .90 & .87 \\
Criteria & $\leq 3$ & $\geq .90$ & $\geq .90$ & $\geq .90$ & $\geq .90$ & $\geq .95$ & $\leq .80$ & $\leq .80$ & $\geq .85$ & $\geq .85$ \\
\hline
\end{tabular}

Table 7 that shows the concordance coefficients of the mediator model given in Figure 4 reveals that all concordance coefficients are good. The findings show that the variable of spousal self-disclosure has a full mediator role between spousal support and marital satisfaction. In addition to all these findings, the "Bootstrapping" method was used to verify the statistical significance of the full mediation of the variable of spousal between spousal support and marital satisfaction.

Bootstrapping is a non-parametric statistical conclusion that allows "re-sampling" or "creation of a new dataset" by iterative expansion of the dataset of the study (Mooney, 1996). B different observation sets are created by a desired number of iterations with re-sampling method and direct, indirect and total effects obtained by mediation analysis are derived from this dataset (Burmaoğlu, Polat, \& Meydan, 2013). Bootstrapping is an analytical instrument for showing the statistical significance of an indirect effect in mediator modeling, which is used frequently in the field of psychology in particular (Koopman et al., 2015). In recent years, it has become popular in studies as a useful and powerful method in testing the significance of mediation hypotheses. It is more popular than other mediation tests (e.g. Sobel test) for a lower rate of type 1 errors (Koopman et al., 2015). In this model, the Bootstrap (BC, 95\%) method (1000) was implemented through AMOS 20 to test the statistical significance of indirect effects. The findings from which this analysis result was derived is given in Table 8 .

Table 8

Coefficients of the Standardized Total, Direct and Indirect Paths in the Renewed Model

\begin{tabular}{lcc}
\hline Paths & \multicolumn{2}{c}{ Standardized Coefficients $(\beta)$} \\
\hline Spousal Support & & Self-disclosure to Spouse \\
Total & $.88^{*}$ & \\
Direct & $.88^{*}$ & \\
Indirect & - & \\
Spousal Support & & \\
Total & $.82^{*}$ & \\
Direct & .11 & \\
Indirect & $.71^{*}$ & \\
Self-disclosure to Spouse & Marital Satisfaction \\
Total & $.81^{*}$ & \\
Direct & $.81^{*}$ & \\
Indirect & - & \\
$* p<.05$. & &
\end{tabular}


The standardized path coefficients for the full mediator model are given in Figure 5.

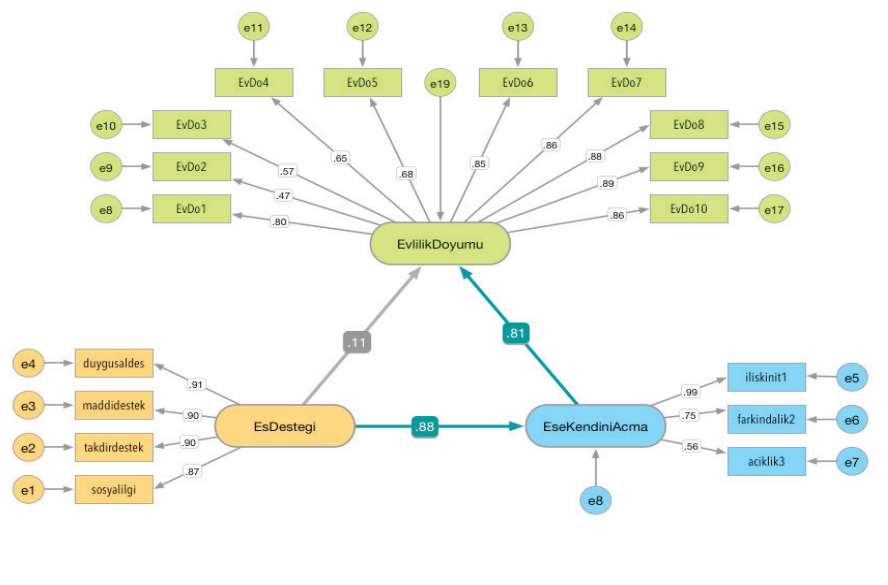

$* p<.05$.

Figure 5. Standardized path coefficients for the full mediator model (Full mediator effect of spousal self-disclosure).

For a mediator role, first there should be a significant relationship between the predictor variable $(\mathrm{X})$ and the predicted variable $(\mathrm{Y}), \mathrm{X}$ should have a significant relationship with the mediator variable (M) and $\mathrm{M}$ should have a significant relationship with Y (Jose, 2013). In other words, it is a prerequisite for all relationships to be significant to look for a mediation effect. In social sciences, mediation is the name of those models where the effect of a variable mediates or interferes in a third variable through a second variable (Fritz \& MacKinnon, 2007). It is possible to characterize mediation effect as full or partial. Once the mediator variable (M) is added to the model, if the relationship between $\mathrm{X}$ and $\mathrm{Y}$ loses significance, this effect is called full mediation, and if the relationship between $\mathrm{X}$ and $\mathrm{Y}$ maintains its statistical significance but some decline is seen in the level of the standardized value in this relationship, this effect is called partial mediation. In the light of this information, directly and indirectly standardized coefficients of the suggested model $(\beta=.88, \mathrm{p}<.05)$ revealed a directly significant relationship between spousal support and spousal self-disclosure, and a directly significant relationship $(\beta=.81, p<.05)$ between spousal self-disclosure and marital satisfaction. Lastly, the direct relationship between spousal support and marital satisfaction $(\beta=.11, \mathrm{p}>.05)$ was not found to be significant. As can be seen in Figure 6, while spousal support does not predict marital satisfaction significantly in direct relationship $(\beta=.11, p>.05)$, when the variable of spousal self-disclosure was added to the model as a mediator variable, the relationship between marital satisfaction and spousal support $(\beta=.71, \mathrm{p}<.05)$ was found to be statistically significant. This significant relationship proves that the variable of spousal self-disclosure plays a full mediator role in this model. On the other hand, evaluation of the regression equation of the model is important for the explained variance of the model. This finding gives idea about the overall descriptiveness of the model. In this respect, it is seen that the 
explained variance of this model whose full mediator role was proven by the analyses made was $87 \%\left(R^{2}=0.869\right)$.

In conclusion, based on our findings, it is fair to say that the variable of spousal self-disclosure has a full mediator role in the relationship between the variables of spousal support and marital satisfaction, and that the SEM formed for this purpose was confirmed. In the light of these analyses, it is seen that the research hypothesis was verified. Accordingly, as can be seen in the model given in Figure 2, the spousal support variable predicts indirectly and significantly through the variable of spousal self-disclosure $(\beta 1=.16 ; \beta 2=.92 p<.000)$. In the light of this finding, the hypothesis that "The mediator role of the variable of spousal self-disclosure in the relationship between spousal support and marital satisfaction is statistically significant" is verified. The results of the sub-hypothesis required for testing this mediator model are as follows:

As seen in Figure 1, the variable of spousal support directly and significantly predicts marital satisfaction $(\beta 1=.84, p<.000)$; as seen it Figure 2, spousal self-disclosure directly and significantly predicts marital satisfaction $(\beta 1=.92, p<.000)$; and as seen in the model in which the mediation effect among the three variables is tested in Figure 3 , the variable of spousal self-disclosure has a full mediator role in the relationship between spousal support and marital satisfaction $(\beta 1=.89 ; \beta 2=.92, p<.000)$. In the light of these findings, it is seen that all 3 sub-hypotheses of the study are confirmed.

\section{Discussion}

This study verifies the hypothesis that "The mediator role of the variable of spousal self-disclosure in the relationship between spousal support and marital satisfaction is statistically significant". In other words, the mediation effect of the variables of spousal self-disclosure and the spousal support explain marital satisfaction. Based on this finding, the direction and the theoretical background of the relationship between the variables of spousal support and spousal self-disclosure should be examined.

Before starting to discuss the mediation effect, when the sub-hypotheses are examined individually, the literature (Fritz \& MacKinnon, 2007; Jose, 2013) primarily expects the direct relationships among all variables in the mediation model to fulfill certain assumptions for a mediation effect, i.e. indirect relationships in a model. Accordingly, the hypothesis that "Spousal support is a direct and significant predictor of marital satisfaction", which was tested as the first sub-hypothesis, is verified. According to several studies, spousal support has a remarkable role in maintaining well-being in a continuing romantic relationship (Sullivan \& Davilla, 2010). According to Goldsmith (2004), the ability of spouses to share bad moments as much as good ones, openly talk about their problems and get each other's support in the face of challenges are important predictors of their satisfaction with their 
relationship. The present study was consistent with this finding of Goldsmith (2004). It is possible to encounter findings of the significance of the relationship between marital satisfaction and spousal support. Accordingly, there is a positive and significant relationship between marital satisfaction and spousal support, and spousal support is considered an important variable in predicting marital satisfaction in a lot of studies. This finding is also similar to those of Acitelli and Antonucci (1994), Brown, Orbuch, and Maharaj (2010), Çağ and Yıldırım (2013), Dehle, Larsen, and Landers (2001), Stone and Shackelford (2007), and Verhofstadt, Lemmens, and Buysse (2013). Furthermore, spousal support in a marriage reduced depressive symptoms according to Monroe, Bromet, Connell, and Steiner (1986), plays an important role in reducing the pressures and tensions in marriage according to Roskies and Lazarus (1980), and is an active factor in resolution of domestic conflicts according to Berkowitz and Perkins (1984). Drawing upon these findings, one can say that in addition to a direct predictor of marital satisfaction, spousal support may affect the quality or satisfaction of marriage positively through indirect effects such as reducing depressive symptoms and resolving conflicts by better coping strategies.

The second sub-hypothesis confirms the hypothesis that "Spousal self-disclosure predicts marital satisfaction directly and significantly" whereby the other direct relationship is tested. This finding is consistent with many findings in the literature. Several studies establish a relationship between the satisfaction with a relationship and self-disclosure (Burke, Weir, \& Harrison, 1976; Hendrick, 1981; Jorgensen \& Gaudy, 1980; Laurenceau, Feldman Barrett, \& Pietromonaco, 1998; Tolsdetd \& Stokes, 1984). Self-disclosure is a positive and significant predictor of marital satisfaction. In sum, spouses that disclose themselves to each other more tend to be more satisfied with their marriage (Hansen \& Schuldt, 1984; Hendrick, 1981; Jorgensen \& Gaudy, 1980). In parallel, Davidson, Baldwick, and Halverson (1983) found that individuals who perceive a higher self-disclosure from their spouse are more satisfied with their marriage. It was concluded by the same study that spouses with similar forms of selfdisclosure are more harmonious in their marriage. According to Sprecher (1987), self-disclosure does not only affect satisfaction with a relationship but also affects the stability, i.e. longevity of relationships positively. According to this argument, it is fair to say that there is a linear correlation between spousal self-disclosure and marital satisfaction. In addition, Meeks, Hendrick, and Hendrick (1998) reported that the variable of self-disclosure is a predictor of a high level of satisfaction for flirting couples. Likewise, Jones (1991) reported that self-disclosure is also a positive predictor of satisfaction with friendships.

The finding of this study that self-disclosure is an important variable that significantly predicts marital satisfaction is supported by other studies on this subject (Bograd \& Spilka, 1996; Davidson et al., 1983; Finkenauer \& Hazam, 2000; Hansen \& Schuldt, 
1984; Jorgensen \& Gaudy, 1980; Meeks, 1996; Schumm, Barnes, Jurich, \& Bugaighis, 1986). In parallel with those studies, Rosenfeld and Bowen (1991) found that individuals with a high level of self-disclosure also have a high marital satisfaction whereas individuals with a low self-disclosure tend to have the lowest marital satisfaction. Similarly, Millar and Millar (1998) reported that women who perceive a lower selfdisclosure from their husband than their own self-disclosure have a lower satisfaction with their relationship. On the other hand, Levinger and Sehn (1967) found in contrast to this finding that marital satisfaction is little related to self-disclosure.

While the first two sub-hypotheses test the significance of the direct relationship among the variables, when these three variables are included together in the model, the sub-hypothesis that "Spousal self-disclosure is a full mediator in the relationship between spousal support and marital satisfaction". It is possible to say that this finding bears similarities to the finding of Lee (2016). Lee (2016) reported that self-disclosure raised satisfaction with a relationship by enhancing the intimacy between the partners. Gilbert (1976) reported that intimacy in a relationship is a very special example of selfdisclosure. It is also very important to improve self-disclosure to improve social support. Accordingly, one may think that even if self-disclosure does not trigger satisfaction with a relationship, it contributes to marital satisfaction indirectly by enhancing the intimacy and bonds between the partners. At this stage, according to Chaikin and Derlega (1974), intimacy between individuals increases with a higher self-disclosure and as intimate conversations increase, the amount of information that they give about themselves grows. Again, according to Chaikin and Derlega (1974), as an individual trusts their partner and starts to give accounts of their personal problems in a relationship that has advanced to this stage, their partner may be satisfied with the relationship, knowing that they are trusted and considered important in the relationship, and the self-disclosing partner may be satisfied with the relationship, knowing that they have a partner to tell their personal problems and that they would be listened and supported by their partner. Edwards, Rose, Edwards, and Singer (2008) made the conclusion that communication and interaction patterns that provide satisfaction and a sense of value have a considerable effect on perception of social support as positive and sufficient by the partner. Again, in parallel with this finding and all other findings mentioned above, the present study expressly identifies and supports the reasons for the status of spousal self-disclosure as a strong predictor of the variable of marital satisfaction.

Many studies have addressed both self-disclosure in communication patterns of close relationships and spousal self-disclosure. In those findings, it is seen that one's perceived self-disclosure of their partner has a more positive effect in clinching the love and affection between the partners compared to one's self-disclosure to their partner (Sprecher, 1987). Collins and Miller (1994) made similar findings and reported that self-disclosure plays a central part in development, progression and 
strengthening of relationships, and that the interaction between a self-disclosing individual and a listening individual has an important role and effect on the level of self-disclosure as well as the level of loving and being loved. Jourard (1971) also argued that self-disclosure is a necessary communication pattern for improvement of both physiological and psychological health as well as emergence and development of interpersonal relationships. According to Jourard (1971), an individual, by disclosing themselves frankly to another individual, can learn about different aspects of another individual's character, discover and understand different needs of that individual, and offer support to them. In the light of this information, one can say that married couples who disclose themselves to each other more deeply and intimately have stronger and more effective perceptions of intimacy and support. Thus, married individuals can use the advantages of self-disclosure to act more flexibly and as needed so that they can support their partner better. Since it is easier to know about the expectations and the kind of social support needed by an individual who discloses themselves to their spouse more easily, it is easier to offer such support. Therefore, a well-functioning mechanism of self-disclosure makes the exchange of social support between partners more fluent, clear and fit for their needs.

According to Doell (2014), emotional support offered by partners to each other is crucial in development and progress of a romantic relationship. Moreover, Monadi (2004) found that self-disclosure is more closely related to the level of marital satisfaction enjoyed by women than do men (cited in Rostami, Ghazinour, and Richter, 2013). In addition, according to Bak et al. (2014) self-disclosure is positively and significantly correlated with social support, and the strong effect of self-disclosure on well-being of individuals is completely attributable to the mediator role of perceived social support. Similarly, Lee, Noh, and Koo (2013) found that there is a positive correlation between self-disclosure and social support, and that the effect of selfdisclosure on well-being is completely attributable to social support. The present study revealed in parallel with the findings of Bak et al. (2014) and Lee et al. (2013) that the variable of self-disclosure has a mediator role in the predictor status of social support for marital satisfaction. According to this, spousal support explains marital satisfaction through the mediator effect of self-disclosure.

In consistence with this finding of the present study, Laurenceau, Feldman Barrett, and Rovine (2005) found that the sense of responsibility and value felt by the speaking or self-disclosing individual has a mediator role in the relationship between self-disclosure of an individual and the intimacy that they feel for the other individual. In parallel with this finding, in the present study, the variable of spousal self-disclosure, as one of the sources of social support, has a mediator role in perception of the support received from the spouse. In sum, the strength of spousal support or its effect on marital satisfaction is only made possible or facilitated by a deep, sincere and broad self-disclosure. Another 
finding of the present study was that this model that is considered a full mediator with a high explanation rate by explaining $87 \%\left(R^{2}=0.869\right)$ of the explained variance. Multiple correlation squared $\left(R^{2}\right)$ value is considered in evaluation of the predictive power of a dependent variable in regression and structural equation model analyses where the predictiveness of a group of variable is tested on a single or multiple dependent varibles (Jain, 1994 as cited in Bentler \& Raykov, 2000). Based on this information, it is fair to say that the model has a fairly high value of explained variance and the model has a high explaining power on the variable of marital satisfaction.

In parallel with all these findings, this model whereby the mediator role of the variable of "Spousal Self-Disclosure" is analyzed in significant prediction of the dependent variable of "Marital Satisfaction" of the variable of "Spousal Support" was verified with all its sub-problems and was found to have sufficient concordance coefficients. To sum up the results, the latent variable of "Spousal Support" directly and significantly predicts "Marital Satisfaction", and the latent variable of "Spousal Self-Disclosure" directly and significantly predicts "Marital Satisfaction". Also, the mediator role of the variable of "Spousal Self-Disclosure" in the relationship between "Spousal Support" and "Marital Satisfaction" is statistically significant. The ideas that were found by a synthesis of the present study and the findings in the literature show that the direct effect of the variable of spousal support on marital satisfaction is largely explicable by reference to the variable of spousal self-disclosure. Accordingly, while spousal support is not a strong variable in explaining marital satisfaction, inclusion of the variable of spousal self-disclosure to enhance the indirect effect provided that variable with a significant predictiveness on marital satisfaction.

In parallel with all these findings, certain suggestions were made for discussion of the concept of marital satisfaction in future studies. Accordingly, marital satisfaction was analyzed under a structural model with the variables of spousal support and spousal self-disclosure. Marital satisfaction may be examined with different variables that may be supported with theoretical grounds. In this study, the relationship among the variables were addressed by a strong analysis using structural equation modeling. However, marital satisfaction may be re-addressed using different variables and statistical methods such as regression in other studies. In addition, psychological counselors, psychologists or psychiatrists working in the field may respond in their research or studies without ignoring the fact that spousal self-disclosure or spousal support affect marital satisfaction as well as spousal self-disclosure and perceived spousal support. Specialists may inform couples during the period of psychological counseling or therapy about the meaning and importance of "Spousal Self-Disclosure" and "Spousal Support". Also, spousal self-disclosure and spousal support modules may be included in relationship enhancement or marriage preparation programs for enhancement of marital satisfaction. 
The present study has certain limitations. The study is limited with participants who live in Ankara, have a wage-earning job and are at least high-school graduates. Majority of the study data was collected from the academic and administrative personnel of a major university in Ankara. At least $80 \%$ of this group hold a bachelor's degree or above. Therefore, the findings of the study may only be generalized to the individuals with similar backgrounds.

\section{References}

Acitelli, L. K., \& Antonucci, T. C. (1994). Gender differences in the link between marital support and satisfaction in older couples. Journal of Personality and Social Psychology, 47(4), 688-698. http://dx.doi.org/10.1037/0022-3514.67.4.688

Altman, I., \& Taylor, D. A. (1973). Social penetration: The development of interpersonal relationships. Holt: Rinehart \& Winston.

Ampuero, M. (2014). Efficacy of cultural-based psychoeducational group therapy for increasing marital satisfaction among Latino couples (Doctoral dissertation). Available from ProOuest Dissertations and Theses database. (UMI No.3669689)

Bak, J., Lin, C. Y., \& Oh, A. (2014). Self-disclosure topic model for Twitter conversations. Association for Computational Linguistics, 42, 1986-1996. http://dx.doi.org/10.3115/v1/w14-2706

Barnes, H. L., Schumm, W. R., Jurich, A. P., \& Bollman, S. R. (1984). Marital satisfaction: Positive regard versus effective communications as explanatory variables. The Journal of Social Psychology, 123(1),71-78. http://dx.doi.org/10.1080/00224545.1984.9924515

Bentler, P. M., \& Raykov, T. (2000). On measures of explained variance in nonrecursive structural equation models. Journal of Applied Psychology, 85(1), 125-131. http://dx.doi. org/10.1037/0021-9010.85.1.125

Berkowitz, A. D., \& Perkins, H. W. (1984). Stress among farm women: Work and family as interacting systems. Journal of Marriage and the Family, 46(1), 161-166. http://dx.doi. org $/ 10.2307 / 351874$

Biehle, S. N., \& Mickelson, K. D. (2012). Provision and receipt of emotional spousal support: The impact of visibility on well-being. Couple and Family Psychology: Research and Practice, 1(3), 244-251. http://dx.doi.org/10.1037/a0028480

Billeter, C. B. (2002). An exploration of eight dimensions of self-disclosure with relationship satisfaction (Master's thesis, Virginia Polytechnic Institute and State University, Virginia). Retrieved from http://scholar.lib.vt.edu/theses/available/etd-08092002-135137/

Berscheid, E., \& Regan, P. (2005). The psychology of interpersonal relationships. New Jersey: Prentice Hall.

Blood, R. O. (1969). Marriage (2nd ed.). New York: The Free Press.

Bograd, R., \& Spilka, B. (1996). Self-disclosure and marital satisfaction in mid-life and late-life remarriages. The International Journal of Aging and Human Development, 42(3), 161-172. http://dx.doi.org/10.2190/w87m-wck7-mhtt-n34f

Brock, R. L., \& Lawrence, E. (2010). A Unified and multifaceted approach to examining support transactions in marriage (Chapter 2). In K. S. Pearlman (Ed.), Marriage roles: Stability and conflict. New York: Nova Science Publishers. 
Brown, E., Orbuch, T. L., \& Maharaj, A. (2010). Social networks and marital stability among black American and white American couples (Chapter 13). In K. T. Sullivan \& J. Davilla (Eds.), Support processes in intimate relationships. New York: Oxford University Press.

Burgess, E. W., Locke, H. J., \& Thomes, M. M. (1963). The family: From institution to companionship (3rd ed.). New York: American Book Company.

Burke, R. J., Weir, T., \& Harrison, D. (1976). Disclosure of problems and tensions experienced by marital partners. Psychological Reports, 38(2), 531-542. http://dx.doi.org/10.2466/ pr0.1976.38.2.531

Burmaoğlu, S., Polat, M., \& Meydan, C. H. (2013). Örgütsel davranış alanında ilişkisel analiz yöntemleri ve Türkçe yazında aracılık modeli kullanımı üzerine bir inceleme. Anadolu Üniversitesi Sosyal Bilimler Dergisi, 13(1), 13-26.

Büyüköztürk, Ş. (2006). Sosyal bilimler için veri analizi: İstatistik, araştırma deseni SPSS uygulamaları ve yorum. Ankara: Pegem A Yayıncılık.

Canbulat, N., \& Cihangir Çankaya, Z. (2014). Evli bireylerin öznel iyi olma düzeylerinin yordanmas1. Ege Eğitim Dergisi, 15(2), 556-576. http://dx.doi.org/10.12984/eed.67597

Caughlin, J. P., \& Huston, T. L. (2006). The affective structure of marriage (Chapter 8). In A. L. Vangelisti \& D. Perlman (Eds.), The Cambridge handbook of personal relationships. New York: Cambridge University Press.

Cayanus, J. L., \& Martin, M. M. (2004). An instructor self-disclosure scale. Communication Research Reports, 21(3), 252-263. http://dx.doi.org/10.1080/08824090409359987

Chaikin, A. L., \& Derlega, V. J. (1974). Self-disclosure. Morristown: General Learning Press.

Collins, N. L., \& Miller, L. C. (1994). Self-disclosure and liking: A meta-analytic review. Psychological Bulletin, 116(3), 457-475. http://dx.doi.org/10.1037/0033-2909.116.3.457

Coyne, J. C., \& DeLongis, A. (1986). Going beyond social support: The role of social relationships in adaptation. Journal of Consulting and Clinical Psychology, 54(4), 454-460. http://dx.doi. org/10.1037/0022-006x.54.4.454

Cox, F. D. (2006). Human intimacy: Marriage, the family, and its meaning. Belmont, CA: Thomson/ Wadsworth.

Critelli, J. W., \& Dupre, K. M. (1978). Self-disclosure and romantic attraction. The Journal of Social Psychology, 106(1), 127-128. http://dx.doi.org/10.1080/00224545.1978.9924155

Cupach, W. R., \& Comstock, J. (1990). Satisfaction with sexual communication in marriage: Links to sexual satisfaction and dyadic adjustment. Journal of Social and Personal Relationships, 7(2), 179-186. http://dx.doi.org/10.1177/0265407590072002

Cüceloğlu, D. (1994). İçimizdeki çocuk (7th ed.). İstanbul: Remzi Kitabevi.

Çağ, P., \& Yıldırım, İ. (2013). Evlilik doyumunu yordayan ilişkisel ve kişisel değişkenler. Türk Psikolojik Danışma ve Rehberlik Dergisi, 4(39), 13-23.

Çağ, P., \& Yıldırım, İ. (2017). Eşe kendini açma ölçeği: Geçerlik ve güvenirlik çalışması. Türk Psikolojik Danışma ve Rehberlik Dergisi, 7(47), 99-111.

Çelik, H. E., \& Yılmaz, V. (2016). LISREL 9.1 ile yapısal eşitlik modellemesi: Temel kavramlar, uygulamalar ve programlama. İstanbul: Anı Yayınları.

Çokluk, Ö., Şekercioğlu, G., \& Büyüköztürk, Ş. (2010). Sosyal bilimler için çok değişkenli istatistik SPSS ve LISREL uygulamaları. Ankara: PegemA Yayıncılık. 
Davidson, B., Balswick, J., \& Halverson, C. (1983). Affective self-disclosure and marital adjustment: A test of equity theory. Journal of Marriage and the Family, 45(1), 93-102. http://dx.doi.org/10.2307/351298

Dehle, C., Larsen, D. \& Landers, J. E. (2001). Social support in marriage. The American Journal of Family Therapy, 29(4), 307-324. http://dx.doi.org/10.1080/01926180152588725

Demir, M. (2010). Close relationships and happiness among emerging adults. Journal of Happiness Studies, 11(3), 293-313. http://dx.doi.org/10.1007/s10902-009-9141-x

Derlega, V. J., \& Chaikin, A. L. (1976). Norms affecting self-disclosure in men and women. Journal of Consulting and Clinical Psychology, 44(3), 376-380. http://dx.doi.org/10.1037/0022-006x.44.3.376

Derlega, V. J., Winstead, B. A., \& Greene, K. (2007). Self-disclosure and starting a close relationship (pp.153-174). In S. Sprecher, A. Wensel, \& J. Harvey (Eds.), Handbook of relationship beginnings. New York: Psychology Press.

Dindia, K. (2000). Self-disclosure, identity and relationship development: A dialectical perspective (Chapter 9). In K. Dindia \& S. Duck (Eds.), Communication and personal relationships. England: John Wiley.

Doell, K. G. (2014). The word feel as a linguistic device in self-disclosure and enacted social support (Doctoral dissertation). Available from ProOuest Dissertations and Theses database. (UMI No.NS28484)

Duck, S. (1988). Relating to others. Open University Press.

Edwards, A. P., Rose, L. M., Edwards, C., \& Singer, L. M. (2008). An investigation among implicit personal theories of communication, social support and loneliness. Human Communication, 11(4), 437-454.

Eskin, M. (2012). Evlilik terapisi için başvuran çiftlerin evlilik doyumu ve evlilik terapisiyle hakkındaki görüşleriyle ilişkili etmenler. Klinik Psikiyatri, 15(1), 226-237.

Fincham, F. D., \& Linfield, K. J. (1997). A new look at marital quality: Can spouses feel positive and negative about their marriage? Journal of Family Psychology, 11(4), 489-502. http://dx.doi. org/10.1037/0893-3200.11.4.489-502

Finkenauer, C., \& Hazam, H. (2000). Disclosure and secrecy in marriage: Do both contribute to marital satisfaction? Journal of Social and Personal Relationships, 17(2), 245-263. http:// dx.doi.org/10.1177/0265407500172005

Fletcher, G. J. O., Simpson, J. A., Campbell, L., \& Overall, N. C. (2013). The science of intimate relationships. Oxford: Wiley-Blackwell.

Fritz, M. S., \& MacKinnon, D. P. (2007). Required sample size to detect the mediated effect. Psychological Science, 18(3), 233-239. http://dx.doi.org/10.1111/j.1467-9280.2007.01882.x

Gable, S. L., \& Algoe, S. B. (2010). Being there when things go right: Support processes for positive events (Chapter 8). In K. T. Sullivan \& J. Davilla (Eds.), Support processes in intimate relationships. New York: Oxford University Press.

Gilbert, S. J. (1976). Self disclosure, intimacy and communication in families. Family Coordinator, 25(3), 221-231. http://dx.doi.org/10.2307/582335

Gillham, J. E., \& Seligman, M. E. P. (1999). Footsteps on the road to a positive psychology. Behaviour Reseacrh and Therapy, 37, 163-173. http://dx.doi.org/10.1016/s0005-7967(99)00055-8

Goldsmith, D. J. (2004). Communicating social support. New York: Cambridge University Press.

Gottman, J. M., Coan, J., Carrere, S., \& Swanson, C. (1998). Predicting marital happiness and stability from newlywed interactions. Journal of Marriage and The Family, 60(1), 5-22. http:// dx.doi.org/10.2307/353438 
Gottman, J. M., Murray, J. D., Swanson, C. C., Tyson, R., \& Swanson, K. R. (2002). The mathematics of marriage: Dynamic nonlinear approach. Cambridge, MA: MIT Press.

Greene, K., Derlega, V. J., \& Mathews, A. (2006). Self-disclosure in personal relationships. (Chapter 22). In A. L. Vangelisti \& D. Perlman (Eds.), The Cambridge handbook of personal relationships. New York: Cambridge University Press.

Hansen, J. E., \& Schuldt, W. J. (1984). Marital self-disclosure and marital satisfaction. Journal of Marriage and the Family, 46(4), 923-926. http://dx.doi.org/10.2307/352541

Harvey, J. H., \& Omarzu, J. (1999). Minding the close relationship: A theory of relationship enhancement. United States of America: Cambridge University Press.

Hendrick, S. S. (1981). Self-disclosure and marital satisfaction. Journal of Personality and Social Psychology, 40(6), 1150-1159. http://dx.doi.org/10.1037/0022-3514.40.6.1150

Hetherington, E. M. (2003). Intimate pathways: Changing pattems in close personal relationships across time. Family Relations, 52(4),318-331.http://dx.doi.org/10.1111/j.1741-3729.2003.00318.x

Hooper, D., Coughlan, J., \& Mullen, M. (2008). Structural equation modeling: Guidelines for determining model fit. The Electronic Journal of Business Research Methods, 6(1), 53-60.

Horwitz, A. V., McLaughlin, J., \& Raskin White, H. (1998). How the negative and positive aspects of partner relationships affect the mental health of young married people. Journal of Health and Social Behavior, 39(2), 124-136. http://dx.doi.org/10.2307/2676395

Hu, L., \& Bentler, O. M. (1999). Cutoff criteria for fit indexes in covariance structure analysis: Conventional criteria versus new alternatives. Structural Equation Modeling: A Multidisciplinary Journal, 6(1), 1-55. http://dx.doi.org/10.1080/10705519909540118

Jensen, J., Rauer, A., \& Volling, B. (2013). A dyadic view of support in marriage: The critical role of men's support provision. Sex Roles, 68(7-8), 427-438. http://dx.doi.org/10.1007/s11199-012-0256-x

Jones, D. C. (1991). Friendship satisfaction and gender: An examination of sex differences in contributors to friendship satisfaction. Journal of Social and Personal Relationships, 8(2), $167-$ 185. http://dx.doi.org/10.1177/0265407591082002

Jones, E. (1994). Family systems therapy: Developments in Milan systemic therapies. Chichester: John Wiley.

Jorgensen, S. R., \& Gaudy, J. C. (1980). Self-disclosure and satisfaction in marriage: The relation examined. Family Relations, 29(3), 281-287. http://dx.doi.org/10.2307/583847

Jose, P. E. (2013). Doing statistical mediation \& moderation. New York: The Guilford Press.

Jose, O., \& Alfons, V. (2007). Do demographics affect marital satisfaction? Journal of Sex and Marital Therapy, 33(1), 73-85. http://dx.doi.org/10.1080/00926230600998573

Jourard, S. M. (1959). Self-disclosure and other cathexis. The Journal of Abnormal and Social Psychology, 59(3), 428. http://dx.doi.org/10.1037/h0041640

Jourard, S. M. (1971). The transparent self. New York: Litton Educational Publishing.

Jourard, S. M., \& Lasakow, P. (1958). Some factors in self-disclosure. The Journal of Abnormal and Social Psychology, 56(1), 91-98. http://dx.doi.org/10.1037/h0043357

Juvva, S., \& Bhatti, R. S. (2006). Epigenetic model of marital expectations. Contemporary Family Therapy, 28(1), 61-72. http://dx.doi.org/10.1007/s10591-006-9695-2

Kline, R. B. (2005). Principles and practice of structural equation modeling (2nd ed.). NY: The Guillford Press. 
Kline, R. B. (2011). Principles and practice of structural equation modeling (3rd ed.). NY: The Guillford Press.

Knoll, N., Kienle, R., Bauer, K., Pfüller, B., \& Luszczynska, A. (2007). Affect and enacted support in couples undergoing in vitro-fertilization: When providing is better than receiving. Social Science \& Medicine, 64(9), 1789-1801. http://dx.doi.org/10.1016/j.socscimed.2007.01.004

Koopman, J., Howe, M., Hollenbeck, J. R., \& Sin, H. P. (2015). Small sample mediation testing: Misplaced confidence in bootstrapped confidence intervals. Journal of Applied Psychology, 100(1), 194-202. http://dx.doi.org/10.1037/a0036635

Kublay, D., \& Oktan, V. (2015). Evlilik uyumu: Değer tercihleri ve öznel mutluluk açısından incelenmesi. Türk Psikolojik Danışma ve Rehberlik Dergisi, 5(44), 25-35.

Lantz, H. R., \& Snyder, E. C. (1969). Marriage: An examination of the man-woman relationship. New York: John Wiley \& Sohn.

Laurenceau, J. P., Feldman Barrett, L., \& Pietromonaco, P. R. (1998). Intimacy as an interpersonal process: The importance of self-disclosure, partner disclosure and perceived partner responsiveness in interpersonal exchanges. Journal of Personality and Social Psychology, 74(5), 1238-1251. http://dx.doi.org/10.1037/0022-3514.74.5.1238

Laurenceau, J. P., Feldman Barrett, L., \& Rovine, M. J. (2005). The interpersonal process model of intimacy in marriage: A Daily-diary and multilevel modeling approach. Journal of Family Psychology, 19(2), 314-323. http://dx.doi.org/10.1037/0893-3200.19.2.314

Lee, J. (2016). Self-disclosure and relational outcomes: The context-dependent disclosure intimacy satisfaction (Cddis) model (Doctoral dissertation). Available from ProOuest Dissertations and Theses database. (UMI No.10129668)

Lee, K. T., Noh, M. J., \& Koo, D. M. (2013). Lonely people are no longer lonely on social networking sites: The mediating role of self-disclosure and social support. Cyberpsychology, Behavior, and Social Networking, 16(6), 413-418. http://dx.doi.org/10.1089/cyber.2012.0553

Levinger, G. (1970). Marital cohesiveness and dissolution: An integrative review. In P. H. Glasser \& L. N. Glasser (Eds.), Families in crises. New York: Harper \& Row Publishers.

Levinger, G., \& Senn, D. J. (1967). Disclosure of feelings in marriage. Merrill Palmer Quarterly of Behavior and Development, 13(3), 237-249. http://dx.doi.org/10.1007/978-1-4899-3523-6_7

Lucas, R. E., \& Dyrenforth, P. S. (2006). Does the existence of social relationships matter for subjective well-being? In K. D. Vohs \& E. J. Finkel (Eds.), Self and relationships: Connecting intrapersonal and interpersonal processes. New York: Guilford Press.

McNamara, M. L. L., \& Bahr, H. M. (1980). The dimensionality of marital role satisfaction. Journal of Marriage and the Family, 42(1), 45-55. http://dx.doi.org/10.2307/351932

Meeks, B. S. (1996). The effects of self-disclosure, perspective-taking, love attitudes, conflict tactics, and relational competence on relationship satisfaction (Doctoral dissertation). Available from ProOuest Dissertations and Theses database. (UMI No.9623852)

Meeks, B. S., Hendrick, S. S., \& Hendrick, C. (1998). Communication, love and relationship satisfaction. Journal of Social and Personal Relationships, 15(6), 755-773. http://dx.doi. org/10.1177/0265407598156003

Menard, S. (1995). Applied logistic regression analysis: Sage University series on quantitative applications in the social sciences. Thousand Oaks, CA: Sage.

Mertler, C. A., \& Vannatta, R. A. (2005). Advanced and multivariate statistical methods: Practical application and interpretation (3rd ed.). Los Angeles: Pyrczak. 
Millar, K. U., \& Millar, M. G. (1988). Sex differences in perceived self and other disclosure: A case where inequity increases satisfaction. Social Behaviour and Personality, 16(1), 59-64. http:// dx.doi.org/10.2224/sbp.1988.16.1.59

Monroe, S. M., Bromet, E. J., Connell, M. M., \& Steiner, S. C. (1986). Social support, life events and depressive symptoms: A 1-year prospective study. Journal of Consulting and Clinical Psychology, 54(4), 424-431. http://dx.doi.org/10.1037/0022-006x.54.4.424

Mooney, C. Z. (1996). Bootstrap statistical inference: Examples and evaluations for political science. American Journal of Political Science, 40(2), 570-602. http://dx.doi.org/10.2307/2111639

Mossakowski, K. N., \& Zhang, W. (2014). Does social support buffer the stress of discrimination and reduce psychological distress among Asian Americans? Social Psychology Quarterly, 77(3), 1-23. http://dx.doi.org/10.1177/0190272514534271

Nelson-Jones, R. (1999). Creating happy relationships: A guide to partner skills. Cassell: New York.

Nielsen, M. R. (2005). Couples making it happen: Marital satisfaction and what works for highly satisfied couples (Chapter 8). In B. Schneider \& L. J. Waite (Eds.), Being together working apart. Cambridge: Cambridge University Press.

Nystul, M. S. (1999). Introduction to counseling: An art and science perspective. Boston, MA: Allyn and Bacon.

Pateraki, E., \& Roussi, P. (2013). Marital quality and well-being: The role of gender, marital duration, social support and cultural context. In A. Efklides \& D. Moraitou (Eds.), A positive psychology perspective on quality of life (pp. 125-145). Springer Netherlands.

Patrick, S., Sells, J. N., Giordano, F. G., \& Tollerud, T. R. (2007). Intimacy, differentiation, and personality variables as predicators of marital satisfaction. The family journal: counseling and therapy for couples and families, 15(4), 359-367. http://dx.doi.org/10.1177/1066480707303754

Perlman, D., \& Vangelisti, A. L. (2006). The Cambridge handbook of personal relationships. Cambridge University Press.

Regan, P. (2011). Close relationships. New York: Routledge.

Reis, H. T., \& Gable, S. L. (2003). Toward a positive psychology of relationships (Chapter 6). In C. L. M. Keyes \& J. Haidt (Eds.), Flourishing: The positive person and the good life. Washington: American Psychological Association.

Reis, H. T., \& Shaver, P. (1988). Intimacy as an interpersonal process. Handbook of Personal Relationships, 24(3), 367-389.

Rini, C., \& Dunkel-Schetter, C. (2010). The effectiveness of social support attempts in intimate relationships (Chapter 2). In K. T. Sullivan \& J. Davilla (Eds.), Support processes in intimate relationships. New York: Oxford University Press.

Rivero, S. C. (2012). The relationship between psychological partner aggression and depression: Social support as a moderating variable (Master's thesis). Available from ProOuest Dissertations and Theses database. (UMI No.1529327)

Rosenfeld, L. B., \& Bowen, G. L. (1991). Marital disclosure and marital satisfaction: Direct-effect versus interaction-effect models. Western Journal of Communication, 55(1), 69-84. http:// dx.doi.org/10.1080/10570319109374371

Roskies, E., \& Lazarus, R. S. (1980). Coping theory and the teaching of coping skills. In P. O. Davidson \& F. M. Davidson (Eds.), Behavioral medicine: Changing health and life style (pp. 38-69). New York: Brunner/Marzel. 
Rostami, A., Ghazinour, M., \& Richter, J. (2013). Marital satisfaction: The differential impact of social support dependent on situation and gender in medical staff in Iran. Global Journal of Health Science, 5(4), 151-164. http://dx.doi.org/10.5539/gjhs.v5n4p151

Rubin, Z., Hill, C. T., Peplau, L. A., \& Dunkel-Schetter, C. (1980). Self-disclosure in dating couples: Sex roles and the ethic of openness. Journal of Marriage and the Family, 42(2), 305-317. http:// dx.doi.org/10.2307/351228

Russell, R. J., \& Wells, P. A. (1994). Personality and quality of marriage. British Journal of Psychology, 85(2), 161-168. http://dx.doi.org/10.1111/j.2044-8295.1994.tb02516.x

Sarason, B. R., \& Sarason, I. G. (2006). Close relationships and social support: Implications for the measurement of social support (Chapter 23). In A. L. Vangelisti \& D. Perlman (Eds.), The Cambridge handbook of personal relationships. New York: Cambridge University Press.

Schumm, W. R., Barnes, H. L., Bollman, S. R., Jurich, A. P., \& Bugaighis, M. A. (1986). Selfdisclosure and marital satisfaction revisited. Family Relations, 35(2), 241-247. http://dx.doi. org $/ 10.2307 / 583631$

Schumacher, R., \& Lomax, R. (2004). A beginner's guide to structural equation modelling. London: Lawrence Erlbaum Associates, Publishers.

Siebert, D. C., Mutran, E. J., \& Reitzes, D. C. (1999). Friendship and social support: The importance of role identity to aging adults. Social Work, 44(6), 522-533. http://dx.doi.org/10.1093/sw/44.6.522

Sprecher, S. (1987). The effects of self-disclosure given and received on affection for an intimate partner and stability of the relationship. Journal of Social and Personal Relationships, 4(2), 115-127. http://dx.doi.org/10.1177/0265407587042001

Sprecher, S., Metts, S., Burleson, B., Hatfield, E., \& Thompson, A. (1995). Domains of expressive interaction in intimate relationships: Associations with satisfaction and commitment. Family Relations, 44(2), 203-210. http://dx.doi.org/10.2307/584810

Stone, E. A., \& Shackelford, T. K. (2007). Marital satisfaction. Encyclopedia of Social Psychology, 541-545. http://dx.doi.org/10.4135/9781412956253.n323

Sullivan, K. T., \& Davilla, J. (2010). Support processes in intimate relationships. New York: Oxford University Press.

Sungur, M. Z. (2009). Sen, ben ve aramızdaki her şey. İstanbul: Goa Yayınları.

Şimşek, Ö. F. (2007). Yapısal eşitlik modellemesine giriş: Temel İlkeler ve LISREL Uygulamaları. Ankara: Ekinoks Yayınc1l1k.

Tezer, E. (1986). Evli eşler arasındaki çatışma davranışları: Algılama ve doyum (Doctoral dissertation, Hacettepe University, Ankara, Turkey). Retrieved from https://tez.yok.gov.tr/ UlusalTezMerkezi/

Thoits, P. A. (1986). Social support as coping assistance. Journal of Consulting and Clinical Psychology, 54(4), 416-423. http://dx.doi.org/10.1037/0022-006x.54.4.416

Tolstedt, B. E., \& Stokes, J. P. (1984). Self-disclosure and the depenetration process. Journal of Personality and Social Psychology, 46(1), 84-90. http://dx.doi.org/10.1037/0022-3514.46.1.84

Trackey, R. P. (2014). Spousal support and common stressors of nontraditional college students (Doctoral dissertation). Available from ProOuest Dissertations and Theses database. (UMI No.3580946)

Türkiye İstatistik Kurumu. (2015). Evlenme ve boşanma istatistikleri. Retrieved from http://www. tuik.gov.tr/PreHaberBultenleri.do?id=21515 
Uchino, B. N. (2004). Social support and physical health: Understanding the health consequences of relationships. New Haven: Yale University Press.

Vera, E. M., \& Betz, E. (1992). Relationships of self-regard and affective self-disclosure to relationship satisfaction in college students. Journal of College Student Development, 33(5), 422-430.

Verhofstadt, L., Lemmens, G., \& Buysse, A. (2013). Support-seeking, support-provision and support perception in distressed married couples: A multi-method analysis. Journal of Family Therapy, 35(3), 320-339. http://dx.doi.org/10.1111/1467-6427.12001

Wallace, J. E., \& Jovanovic, A. (2011). Occupational similarity and spousal support: A study of the importance of gender and spouse's occupation. Relational Industrielles/Industrial Relations, 66(2), 235-255. http://dx.doi.org/10.7202/1006145ar

Waring, E. M. (1981). Facilitating marital intimacy through self-disclosure. The American Journal of Family Therapy, 9(4), 33-42. http://dx.doi.org/10.1080/01926188108250422

Whisman, M. A., \& Baucom, D. H. (2012). Intimate relationships and psychopathology. Clinical Child Family Psychology Review, 15(1), 4-13. http://dx.doi.org/10.1007/s10567-011-0107-2

Williams, K. (2003). Has the future of marriage arrived? A contemporary examination of gender, marriage and psychological well-being. Journal of Health and Social Behavior, 44(4), 470-487. http://dx.doi.org/10.2307/1519794

Williams, B. K., Sawyer, S. C., \& Wahlstrom, C. M. (2012). Marriages, families, and intimate relationships. Boston: Pearson.

Yetim, Ü. (2001). Toplumdan bireye mutluluk resimleri. İstanbul: Bağlam Yayınları.

Yıldırım, İ. (2004). Eş destek ölçeğinin geliştirilmesi. Psikolojik Danışma ve Rehberlik Dergisi, $3(22), 19-25$.

Zainodin, H. J., \& Yap, S. J. (2013). Overcoming multicollinearity in multiple regression using correlation coefficient. Proceedings of the International Conference on Mathematical Sciences and Statistics, 1557(1), 416-419. http://dx.doi.org/10.1063/1.4823947 